Journal Of Sea Research

December 2016, Volume 118 Pages 103-112

http://dx.doi.org/10.1016/i.seares.2016.11.004

http://archimer.ifremer.fr/doc/00367/47848/

(c) 2016 Published by Elsevier B.V.

\title{
Particles transformation in estuaries: Fe, Mn and REE signatures through the Loire Estuary
}

\author{
Thibault de Chanvalon A. ${ }^{1,2,{ }^{*}{ }^{\star}}$, Metzger E. ${ }^{1}$, Mouret A. ${ }^{1}$, Knoery Joel ${ }^{2}$, Chiffoleau Jean-Francois ${ }^{2}$, \\ Brach-Papa Christophe ${ }^{2}$
}

${ }^{1}$ Univ Angers, CNRS, UMR 6112, LPG,BIAF, F-49045 Angers, France.

2 IFREMER, LBCM, Rue lle Yeu, F-44300 Nantes, France.

*Corresponding author : A. Thibault de Chanvalon, email address : athibaultdc@gmail.com

\begin{abstract}
:
During their transfer across estuaries, particles endure numerous cycles of deposition-resuspension accompanied by several redox oscillations. These oscillations are likely to modify the particles content of redox sensitive metals such as $\mathrm{Fe}, \mathrm{Mn}$ and two rare earth elements (REE): Ce and Eu. The present paper focuses on the fate of particles originating from the Loire Estuary by the study of chemical composition changes of both total and ascorbate-extracted phases. Transformations of particles buried in the sediment are estimated from sediment cores sampled in an estuarine intertidal mudflat Changes affecting particles that are transferred to the ocean are evaluated by comparing the composition of suspended particulate matter (SPM) from riverine time series to coastal marine SPM. Our results show an important decrease of SPM iron content corresponding to a loss of $14.3 \%$ of total iron. However, no iron storage was observed in the intertidal mudflat. Manganese is probably also lost during the transfer but the riverine temporal variability prevents its quantification. The similarity of $\mathrm{Ce}$ and Eu signatures between highly concentrated SPM and sedimentary particles suggests that most estuarine transformations are probably induced by early diagenesis during deposition (and frequently anoxic) periods.
\end{abstract}




\section{Introduction}

Estuaries are important reactors that modify riverine particles before their release into the ocean, controlling therefore the continental input in coastal waters. Estuarine hydrodynamics traps fine particles during low flow periods (Dalrymple et al., 1992). During their storage, particles are shuttled from the water column to the sediment at slack tide, and resuspended during both ebb and flow. When numerous particles are in suspension, they form a localised maximum turbidity zone (MTZ). The drastic increase of suspended particulate matter (SPM) concentration within the MTZ generates immobilization and ultimately a fluid mud. When suspension events are less intense, the settled particles progressively consolidate into muddy sediments. By reducing light penetration, and being rich in organic matter, high particle concentration environments favour heterotrophic bacterial activity and often lead to oxygen depletion. This is compounded when convection is reduced. Consequently, the probability for one particle to be in an oxygen depleted environment increases with increasing particle concentration (water column $<$ MTZ $<$ fluid mud $<$ sediment).

During a suspension event, particles and pore waters are remobilized locally, decreasing therefore the redox potential. New suspended particles will know more oxidative conditions compared to old suspended particles that endure reducing conditions (Abril et al., 1999). Moreover, for particles located in muddy sediments, the formation and abandonment of burrows generate respectively periods of oxic and anoxic conditions (Aller, 1982). Therefore, particles undergo redox oscillations ranging from a few hours for suspension events to several weeks for burrows formation (Meysman et al., 2003). First studies quantifying the impact of redox oscillations on suspended particles were based on observations of estuarine MTZ (Abril et al., 1999) and deltaic mobile mud (Aller, 1998). The different redox-sensitive elements are 
dissolved according to the order predicted by the sequence of microbial anaerobic respiration processes (Froelich et al., 1979). In a predominantly oxic environment affected by short anoxic events, $\mathrm{NO}_{3}{ }^{-}$and $\mathrm{Mn}$ oxides are the most reactive elements (Abril et al., 1999, 2000, 2010; Robert et al., 2004; Audry et al., 2006). At the opposite, in a predominantly anoxic environment with short oxic events, stocks of $\mathrm{NO}_{3}{ }^{-}$and $\mathrm{Mn}$ oxide are quickly exhausted and Fe oxy(hydr)oxides become the most reactive species (Aller, 1998, 2004; Aller and Blair, 2006). Simultaneously to the oxidant consumption, the so called redox sensitive" elements are either trapped or released. Among them, the rare earth elements (REE) Ce and Eu have very close properties compared to other REE due to the progressive filling of the f-electron layer, except that they form different redox couples $\mathrm{Ce}(\mathrm{III}) / \mathrm{Ce}(\mathrm{IV})$ and $\mathrm{Eu}(\mathrm{II}) / \mathrm{Eu}(\mathrm{III})$. Consequently, by comparison to other REE, $\mathrm{Ce}$, and $\mathrm{Eu}$ have the potential to identify redox transformations among the numerous changes induced by other processes.

The overall impact of these oscillations, at the estuary scale, has not been properly investigated. Only few publications tried to correlate SPM composition with sediment processes (Trefry and Presley, 1982; Church, 1986; Regnier and Wollast, 1993; Zwolsman and Van Eck, 1993; Zwolsman and van Eck, 1999; Audry et al., 2007; Andrieux-Loyer et al., 2008). In particular, it is not clear whether the repetition of dissolution/precipitation cycles for Fe and Mn oxides may:

(1) rejuvenate oxides and ultimately increase their bioavailability (Raiswell, 2011),

(2) increase iron oxide crystalline forms due to the preservation of the most crystalline phases during each dissolution cycle (Thompson et al., 2006),

(3) generate a transfer of Fe or Mn oxides from SPM to the sediment (Poulton and Raiswell, 2002; Raiswell, 2006), 
(4) result in an oxide loss for SPM (Moore et al., 1979) due to colloidal / nanoparticles shuttle (Lyons and Severmann, 2006; Lam et al., 2012) which favours downstream Fe or Mn transfer to the open ocean.

Improving our knowledge on processes involving Fe and Mn oxides in estuaries will lead to a better understanding of oceanic iron supply pathways (Raiswell, 2006) and hence, a better description of micro nutrient involved in oceanic primary production (Martin and Fitzwater, 1988). A better understanding of remobilisation of Fe and Mn oxides is also critical for the description of long term storage of organic carbon (Lalonde et al., 2012) and for the estimation of trace metal remobilisation in coastal environments (Négrel, 1997; Turner, 2000). Our study aims to describe the importance of redox transformations in the cycle of reactive $\mathrm{Fe}$ and $\mathrm{Mn}$ in the Loire Estuary. In order to do so, several questions are to be answered:

(1) What are the overall changes of Fe and Mn content in SPM that result from estuarine processes?

(2) Where do most metal losses or gains occur (MTZ versus sediment)?

(3) Are the changes in Fe and Mn content to be linked to transformations of oxide reactivity?

Focusing on the Loire Estuary, we here report Fe/Al and $\mathrm{Mn} / \mathrm{Al}$ ratios from an estuarine intertidal mudflat sediment and from riverine, coastal and estuarine SPM. Three contrasting seasons are sampled in order to obtain the widest range of oxides transformations. Evidence that the chemical changes observed on particles are produced by redox reactions come from Fe and Mn content extracted by an ascorbate leaching and the ratios of $\mathrm{Ce} / \mathrm{La}$ and $\mathrm{Eu} / \mathrm{Sm}$. 


\section{Material and methods}

\subsection{Study site}

The Loire River at Nantes has a $117,045 \mathrm{~km}^{2}$ drainage basin and a mean water discharge of $890 \mathrm{~m}^{3} \mathrm{~s}^{-1}$ (DREAL Pays-de-Loire, 1994). During floods (up to $5200 \mathrm{~m}^{3} \mathrm{~s}^{-1}$ ), freshwater has maximal SPM concentrations of $200 \mathrm{mg} \mathrm{L}^{-1}$ (SOGREAH, 2010) with high Al-Fe oxy(hydr)oxides and/or aluminosilicates (up to $20 \% \mathrm{w} / \mathrm{w}$ for $\mathrm{Al}_{2} \mathrm{O}_{3}$ and $7 \% \mathrm{w} / \mathrm{w}$ for $\mathrm{Fe}_{2} \mathrm{O}_{3}$; Grosbois et al., 2001). During summer, the low flow (down to $120 \mathrm{~m}^{3} \mathrm{~s}^{-1}$ ) has lower SPM concentration with higher calcite and organic matter content due to primary production (up to 25\% w/w and 37\% w/w respectively; Manickam et al., 1985; Grosbois et al., 2001; Gorse et al., 2010). The maximum turbidity zone (MTZ) dynamics at Donges (45 km downstream of Nantes; Fig. 1), is characterized by two re-suspension events of $\sim 3$ hours showing a maximum SPM concentration $1 \mathrm{~h} 30$ before and $1 \mathrm{~h} 30$ after the slack of low tide (network SYVEL, GIP Loire Estuaire). The MTZ is more charged in particles during spring tides and migrate upstream/downstream according to the river water discharge. Saliot et al. (1988) showed that organic matter in the MTZ is mainly terrigenous due to a typical buffering effect of MTZ in which labile organic matter is quickly consumed (Billen et al., 1986; Abril et al., 2002). This buffering effect of the MTZ is further confirmed by the sharp decrease of $\mathrm{C}_{\text {org }}$ with increasing SPM concentration within the MTZ, until reaching a constant value of $\mathrm{C}_{\text {org }}(\mathrm{MTZ})=3-4 \%$ (Billen et al., 1986; Meybeck et al., 1988). Particle residence time in the Loire Estuary ranges between 4 to 10 months (Ciffroy et al., 2003b), i.e. until a flood expels them out of the estuary (Gernez et al., 2015). The Loire Estuary is the main source of coastal SPM in the studied area

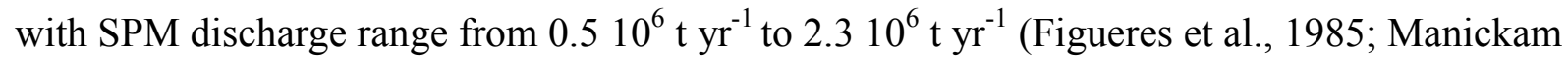
et al., 1985; Migniot, 1993; Négrel, 1997; Jouanneau et al., 1999; Gorse et al., 2010) versus $\sim 0.110^{6} \mathrm{t} \mathrm{yr}^{-1}$ (Jouanneau et al., 1999) for the Vilaine River (Fig. 1). 
Dissolved organic carbon (DOC) concentrations range between 2.4 and $10 \mathrm{mg} \mathrm{L}^{-1}$ with a slight increase during flood (Cauwet and Meybeck, 1987; Gorse et al., 2010). The daily measurements of various parameters of the water column (SYVEL network) reveals a saline stratification mostly during neap tide and flood, as described in Le Douarec (1978). Nutrients are not conservative along the salinity gradient and are highly variable due to primary production and benthic fluxes. Summer concentrations of chlorophyll-a have a median of 14 $\mu \mathrm{g} \mathrm{L} \mathrm{L}^{-1}$ with a yearly maximum above $50 \mu \mathrm{g} \mathrm{L} \mathrm{L}^{-1}$ (Crouzet, 1983; Meybeck et al., 1988; Minaudo et al., 2015). Other processes such as hydrolysis of hydroxyapatite, denitrification in the fluid mud and strong nutrient recycling, marked by algal community switches at low salinity ( $<<1$; Morris et al., 1978; Meybeck et al., 1988), can also be proposed to explain nutrient concentration variations.

\subsection{Sampling}

Estuarine and downstream SPM were collected during three sampling cruises on $\mathrm{N} / \mathrm{O}$ Thalia" according to the salinity gradient in the Loire Estuary and in the coastal area (Figure 1). Two salinity transects during contrasting tidal amplitudes were conducted during each cruise. The first cruise took place in September 2012 (from 24/09/2012 to 28/09/2012, $\underline{\text { http://dx.doi.org/10.17600/12070140) }}$ during a period of stable, low flow (200 $\mathrm{m}^{3} \mathrm{~s}^{-1}$ at Nantes (DREAL Pays-de-Loire, 1994; Fig. S1) and warm water $\left(17^{\circ} \mathrm{C}\right)$. Oxygen depletion, usually observed in this season, was measured a week before (network SYVEL, GIP Loire Estuaire) but not during the cruise. Tidal coefficients at St Nazaire (Fig. 1), based on the range of water level during a tidal oscillation, were of 47 and 80 for the first and second salinity transect, respectively. During the second cruise (from 19/04/2013 to 26/04/2013, 
http://dx.doi.org/10.17600/14007900; Fig. S1), the Loire freshwater discharge decreased from $1800 \mathrm{~m}^{3} \mathrm{~s}^{-1}$ to $1000 \mathrm{~m}^{3} \mathrm{~s}^{-1}$ and tidal coefficient increased from 34 to 103 between the first and the second salinity transect. Water temperature was $14^{\circ} \mathrm{C}$. The third campaign $(01 / 02 / 2014-$ 07/02/2014 http://dx.doi.org/10.17600/13070070) was characterized by a flood water flow (2400 to $2800 \mathrm{~m}^{3} \mathrm{~s}^{-1}$ ) and a tidal coefficient of 113 and 50 for the first and second salinity transect respectively. Water temperature was around $7^{\circ} \mathrm{C}$; wind and sea-state prevented the collection of samples outside the estuary. No riverine particles were sampled during the first cruise. The second and third cruises were preceded by a weekly to biweekly sampling of riverine" particles $(\mathrm{S}=0)$ at Basse-Indre", - Fabarly", - Oudon" and MontJean" respectively 45, 53, 86, $120 \mathrm{~km}$ upstream from St Nazaire.

The duration of each transect was typically of 7 hours and they were performed simultaneously to the ebb tide for downstream transect and during the flood tide for upstream transect. Sometimes, a second day of sampling was necessary to complete the salinity gradient. Water from roughly $1 \mathrm{~m}$ below the surface was continuously pumped using an allTeflon pumping system made of PFA (Perfluoroalkoxy) tubing connected to a piston pump (ASTI, France) and brought into an on-board, pressurized clean room (Chiffoleau et al., 1994; Kraepiel et al., 1997). Discrete samples (2L to 5L) were collected into acid cleaned PFA bottles under a laminar flow hood. Subsamples were then $\mathrm{N}_{2}$ overpressure-filtered through pre-weighed acid-cleaned polycarbonate filters $(0.4 \mu \mathrm{m}$, Nuclepore). After filtration, filters were rinsed with ultrapure water (Milli-Q, Millipore), stored in acid cleaned Petri dishes and frozen. Back to the laboratory, filters dedicated to total extraction were dried in an oven at $50^{\circ} \mathrm{C}$ while filters dedicated to ascorbate extraction were freeze-dried. 
Simultaneously to the three cruises, $20 \mathrm{~cm}$-long sediment cores were sampled at low tide in the mudflat. The sampling site $\left(47^{\circ} 17^{\prime} 8.00^{\prime \prime} \mathrm{N} 2^{\circ} 3^{\prime} 49.00^{\prime \prime} \mathrm{W}\right)$ is located on the un-vegetated part of Les Brillantes mudflat (Fig. 1; the largest mudflat of the Loire Estuary; 1350 ha, GIP Loire Estuaire), below the mean high water neap tide level, approximately 500 meters offshore. There, sediment is mainly composed of silt (92\%) and clay $(6 \%)$ with rare sandy horizons (up to $37 \%$ for $63-2000 \mu \mathrm{m}$ fraction; Benyoucef, 2014). Total organic carbon concentrations range from 2 to $3 \% \mathrm{w} / \mathrm{w}$ and oxygen penetration depth is shallower than $5 \mathrm{~mm}$ (Thibault de Chanvalon et al., 2015). Sediment surface is often recovered by a biofilm with a density varying from $20 \mathrm{mg} \mathrm{m}^{-2}$ in January to $60 \mathrm{mg} \mathrm{m}^{-2}$ in July (Benyoucef et al., 2014). One core $(\varnothing=8.2 \mathrm{~cm})$ was sampled at each campaign and brought to the field laboratory. Within $6 \mathrm{~h}$, the centre of each core was sub-sampled into $2 \mathrm{~mm}, 5 \mathrm{~mm}$, and $1 \mathrm{~cm}$-thick slices to $20 \mathrm{~cm}$ deep. Mud samples were weighed then frozen. During the week after, samples were freezedried and ground in an agate mortar.

\subsection{Analyses}

Total extractions were processed on entire filters loaded with SPM or on $200 \mathrm{mg}$ aliquots of sediment samples, then digested with a mixture of nitric, hydrochloric and hydrofluoric acids and heated up to $130^{\circ} \mathrm{C}$ in closed Teflon bombs (Rantala and Loring, 1990). Digests were then slowly evaporated to dryness and dry residues were taken up in $25 \mathrm{ml} \mathrm{HNO}_{3}(10 \%$, Suprapur(C Merck) by heating up to $130^{\circ} \mathrm{C}$. Analyses of Fe, Al, Mn and REE were performed using an ICP-Q-MS (iCAP Qc, ThermoFisher Scientific) equipped with a Peltier-cooled, quartz cyclonic spray chamber, a $200 \mu \mathrm{L} / \mathrm{mn}$ PFA nebulizer and a Nickel standard cones with insert. Elemental concentrations were determined using external calibration (5 to 6 points) in 
diluted $\mathrm{HNO}_{3}(3 \%)$. Internal standards of ${ }^{115} \mathrm{In}$ and ${ }^{203} \mathrm{Tl}$ were added to all solutions to monitor from instrumental drift. Depending on the measured elements, measurements were performed using standard (STD) or Kinetic Energy Dispersion (KED) modes. For A1, Fe and Mn, STD mode was used, precision (twice the relative standard deviation of 5 measurements) was less than $1 \%$ and accuracy was verified with MESS-3 certified material. For REE analyses, samples were systematically analysed using the KED mode, and special tuning conditions to obtain minimum oxide formation within the plasma. Oxide formation rate was evaluated by computing $\mathrm{CeO} / \mathrm{Ce}$ ratios. During measurements, interferences due to oxide formation with REE elements were checked by injecting a test solution composed of $\mathrm{Pr}, \mathrm{Gd}$ and $\mathrm{Ba}$ and by measuring the resulting signals for $\mathrm{PrO}, \mathrm{GdO}$ and $\mathrm{BaO}$. Corrections appeared to be necessary only for ${ }^{151} \mathrm{Eu}$ and ${ }^{157} \mathrm{Gd}$. Results were normalized to Th that acts as an offset to compare REE-signatures between different samples. Moreover, the Post Archean Australian Shale (PAAS) normalization smooths the variations between different elementary abundances in order to facilitate the description of the REE spectrum. A reference material (BCR-667) was systematically measured every 10 samples to control ICP-Q-MS response. Our results $(\mathrm{n}=15)$ are in good agreement with BCR-667 reference values (Fig. S2). However, the two heaviest $(\mathrm{Yb}, \mathrm{Lu})$ and the two lightest (La, Ce) were systematically slightly underestimated resulting in an error of 6-8\%.

For ascorbate extractions, samples were incubated in an ascorbate reagent (buffered at $\mathrm{pH} 8$ ) during 24 hours (Kostka and Luther, 1994). This technique allows to extract most reactive Fe(III) oxyhydroxides (Raiswell et al., 2010) supposedly close to those potentially reduced by microorganisms (Hyacinthe et al., 2006) as well as reactive $\mathrm{Mn}(\mathrm{III})$ and $\mathrm{Mn}(\mathrm{IV})$ oxides (Anschutz et al., 2005). After extraction, samples were centrifuged (10 min at $3000 \mathrm{rpm}$ ) and 
the supernatant was diluted in $\mathrm{HNO}_{3}\left(0.01 \mathrm{~mol} \mathrm{~L}^{-1}\right)$. Samples were analysed using ICP-AES (Thermo Scientific iCAP 6300 Radial), with a precision (twice the relative standard deviation of ICP-AES triplicates) and accuracy (expressed as the relative difference between calculated and measured values of standards) of less than $1.5 \%$ for both Fe and Mn. Grain size was analysed for $10 \mathrm{SPM}$ samples (bulk water stored in the dark, at $4^{\circ} \mathrm{C}$ ) and for a sediment core from the third campaign, using a Malvern 2000 without preparation treatment (Walling et al., 2000). Analyses were performed less than 4 days after sampling.

\section{Results}

Table 1 lists contents of Al, Fe, Mn and the sum of all REE concentrations ( $\sum$ REE). Riverine and estuarine SPM show high concentrations of $\mathrm{Al}, \mathrm{Fe}$ and $\mathrm{Mn}$ compared to estuarine sediments and especially to downstream SPM. Fe and Al are strongly correlated $\left(r^{2}>0.98\right)$ with significant differences between riverine and coastal $\mathrm{Fe} / \mathrm{Al}$ ratios ( $\mathrm{p}$-value $<10^{-7}$; Fig. $2 \mathrm{a}$ ). Estuarine samples (both sediment and SPM) are distributed between the riverine and coastal regression trend lines. $\mathrm{Mn}$ and $\mathrm{Al}$ are negatively correlated in riverine SPM (Fig. $2 \mathrm{~b} ; \mathrm{r}^{2}=0.66$, $\mathrm{n}=44$, $\mathrm{p}$-value $<10^{-10}$, which contrasts with the positive and season-dependant correlation in coastal SPM (Fig. 2b; $\mathrm{r}^{2}=0.69$ and $0.82, \mathrm{n}=7$ and $25, \mathrm{p}$-value $<10^{-3}$ and $10^{-15}$ for respectively September 2012 and May 2013). In the sediment, distribution patterns of both $\mathrm{Mn}_{\mathrm{asc}}(\mathrm{Mn}$ from ascorbate extraction) and $\mathrm{Mn} / \mathrm{Al}$ profiles (Fig. 3a and 3b) show surface enrichments of which depth and intensity are season-dependant (Sept $2012<$ May $2013<$ Fe 2014). Although it is less intense, $\mathrm{Fe}_{\text {asc }}$ (Fig. 3c) shows a similar surface enrichment. However, the $\mathrm{Fe} / \mathrm{Al}$ profile does not show such a clear trend, even if lower values are located at the bottom of the sediment column (Fig. 3d). The sediment grain size is homogeneous with unimodal 
silty distribution ( $\mathrm{D} 50=10.7 \pm 1.9 \mu \mathrm{m}, \mathrm{n}=41$; data not shown). Some sediment samples present a smooth enrichment around $63 \mu \mathrm{m}$ but all D90 are below $70 \mu \mathrm{m}$. The seasonal dynamics of the sediment and the associated pore water is provided and intensively discussed in Thibault de Chanvalon et al. (submitted).

Normalized concentration of rare earth elements from sediment, riverine and coastal particles are shown in Fig. 4. After Th-PAAS normalization, bell-shaped distributions are observed for nearly all samples. This MREE (from Sm to Ho) enrichment is typical of phases such as organic matter (e.g. Johannesson et al., 2004; Tang and Johannesson, 2010; Freslon et al., 2014), Fe/Mn oxides (e.g. Johannesson et al., 1996; Zhang et al., 1998; Yang et al., 2002; Haley et al., 2004; Lim et al., 2014), apatite (e.g. Grandjean et al., 1987; Hannigan and Sholkovitz, 2001) or carbonate (e.g. Banner et al., 1988). It thus indicates the importance of post-weathered processes even if no specific mechanisms reach consensus (Zhang et al., 1998). However, numerous intersects between different REE spectra can be seen around local maxima for $\mathrm{Ce}$, Eu and Tm (Fig. 4). These slope variations are typically described as "anomalies". Numerous mathematical definitions of "anomalies" exist (e.g. Lawrence and Kamber, 2006). In the present study, only elemental ratios normalized on PAAS elemental ratio are considered (i.e. $\mathrm{Ce} / \mathrm{La}=\mathrm{Ce}_{\text {sample }} / \mathrm{La}_{\text {sample }} / \mathrm{Ce}_{\mathrm{PAAS}} / \mathrm{La} \mathrm{PAAS}_{\mathrm{PAS}}$ ). Therefore, one anomaly around the $\mathrm{n}^{\text {th }}$ REE can be estimated by calculating its ratio vs. its neighbouring REE.

As $\mathrm{Ce} / \mathrm{La}$ and $\mathrm{Ce} / \mathrm{Pr}$ are well correlated $\left(\mathrm{r}^{2}=0.96\right.$, data not shown), they provide the same information and no distinction is made between them. The ratio Ce/La shows a constant value in the sediment $(\mathrm{Ce} / \mathrm{La}=0.88, \mathrm{sd}=0.01, \mathrm{n}=14)$ and in the MTZ compared to other SPM samples (Fig. 5a). The Eu/Sm ratio differentiates the sediment with low $\mathrm{Eu} / \mathrm{Sm}$ ratio from the SPM (Fig. 5b). However, the Eu/Sm ratio in the MTZ decreases with increasing SPM 
concentration until a sediment-like Eu/Sm value (Fig. 5b). Furthermore, the Eu/Sm ratio is correlated with $\mathrm{Fe}_{\text {asc }}\left(\mathrm{r}^{2}=0.55\right.$; p-value $=1.310^{-6}$; Fig. 5c). The $\mathrm{Eu} / \mathrm{Gd}$ ratio (not shown) is weakly correlated with $\mathrm{Eu} / \mathrm{Sm}$. Indeed, few samples from estuarine and riverine SPM present a gap between $\mathrm{Eu} / \mathrm{Gd}$ and $\mathrm{Eu} / \mathrm{Sm}$ which are not correlated with environmental parameters. The $\Sigma$ REE content is buffered-like in the sediment $\left(\Sigma \mathrm{REE}=197 \pm 9 \mathrm{mg} \mathrm{kg}^{-1}, \mathrm{n}=14\right)$ while SPM content, that increases with the SPM concentration, has a wide range from $21 \mathrm{mg} \mathrm{kg}^{-1}$ to $705 \mathrm{mg} \mathrm{kg}^{-1}$ (Fig. 5d). Both $\mathrm{Tm} / \mathrm{Er}$ and $\mathrm{Tm} / \mathrm{Yb}$ variations are too small compared to analytical uncertainties to bring significant information.

\section{Discussion}

\subsection{Working hypotheses}

In order to draw conclusions on the part of mixing from two (or more) SPM sources and that of in situ chemical transformations in the observed variations of metal content in SPM, some working hypotheses are necessary. First, Al will be considered non-mobile and its content exclusively due to terrigenous inputs from the drainage basin. Therefore, normalization of metal content by $\mathrm{Al}$ would allow discarding the mixing of terrigenous and riverine particles. Secondly, since the Loire River drainage basin is the main source of coastal SPM in the studied area, the variations of metal content due to mixing from other drainage basins will be neglected. Thirdly, as all samples are mainly fine silts, metal content changes of bulk SPM due to size-specific sedimentation (e.g. finer particle are typically enriched in metals) would be neglected as well. As a consequence, differences between riverine and coastal SPM will be assumed to be caused by chemical transformations. 


\subsection{River flux control}

Upstream samples (from 4 different locations), show no clear relation between $\mathrm{Al}, \mathrm{Fe}, \mathrm{Mn}$ and distance from Nantes. An analysis of variance (ANOVA) performed on both Fe/Al and Mn/Al with location and date shows systematically a significance of date $(p<0.01)$ and no significance of location (Table S1). The importance of flow and season on chemical composition of upstream SPM has been described by a 2-year time series (Grosbois et al., 2001). As our data mostly describe riverine inputs during flood $\left(\mathrm{Q}>1000 \mathrm{~m}^{3} \mathrm{~s}^{-1}\right.$ for 2013 and 2014 upstream time series), we expected to sample mostly terrigenous particles (Grosbois et al., 2001). However, the alignment of our samples with Grosbois et al. (2001) dataset for low and high flow is clearly shown by Fig. $3 \mathrm{a}\left(\mathrm{r}^{2}=0.96\right)$. Therefore, the Fe concentration of upstream particles is efficiently described by a single terrigenous source (metal rich) mixed with a fraction of metal poor river-borne particles (e.g. calcite, organic matter).

Figure $3 \mathrm{~b}$ shows that two metal rich end-members are necessary to explain the variations of Mn content of riverine particles. Such as Morris et al. (1987), we describe the two mixing phases by: (1) a phase which is always present and shows constant concentration: $S P M_{1}$ and (2) a phase with a variable concentration $S P M_{2}$ according to the river flow. This relation corresponds to the equation below:

$$
C=\frac{S P M_{1}}{S P M_{1}+S P M_{2}}\left(C_{1}-C_{2}\right)+C_{2}
$$

with $\mathrm{C}_{1}$ and $\mathrm{C}_{2}$, being the concentrations of phases 1 and 2 .

A plot of Mn and Al contents versus 1/SPM (Fig. S3) shows that this model explains $67 \%$ and $49 \%$ of $\mathrm{Mn}$ and $\mathrm{Al}$ content variations, respectively. Moreover, this model defines the content of the two phases represented by the red stars in Fig. $2 \mathrm{~b}$ (i.e. $\mathrm{Al}=6.89 \pm 0.85 \%$ and $\mathrm{Mn}=1510$ 
$\pm 220 \mathrm{mg} \mathrm{kg}^{-1}$ for $S P M_{1}$ and $\mathrm{Al}=9.84 \pm 1.30 \%$ and $\mathrm{Mn}=692 \pm 103 \mathrm{mg} \mathrm{kg}^{-1}$ for $\left.S P M_{2}\right)$. The riverine $\mathrm{Mn} / \mathrm{Al}$ variation covers the whole range of $\mathrm{Mn} / \mathrm{Al}$ ratio found in coastal and estuarine SPM. Therefore, the $\mathrm{Mn} / \mathrm{Al}$ ratio is not able to trace estuarine transformations. To sum up, the study of riverine SPM allows defining a riverine end-member only for Fe/Al, therefore allowing identification of estuarine processes.

\subsection{Signature of benthic transformations}

Estuarine processes are mostly induced by the variation of two main environmental parameters:

(1) Daily average salinity around each particle progressively increases as the particles move downstream. However, as particles move slower than the surrounding water, they encounter also salinity oscillations due to tidal cycles. These salinity variations generate exchanges between dissolved phase $(<0.4 \mu \mathrm{m})$ and SPM through processes such as adsorption and desorption (Ciffroy et al., 2003a) or colloids flocculation (e.g. Sholkovitz, 1978; Escoube et al., 2009). Knowing that dissolved iron $\left(\mathrm{Fe}_{\mathrm{d}}\right)$ represents in average $0.45 \%$ of total iron concentration in the Loire Estuary (data not shown), $\mathrm{Fe}_{\mathrm{d}}$ cannot explain the changes observed in the Loire estuarine particles. Furthermore, $\mathrm{Fe}_{\mathrm{d}}$ shows a conservative behaviour between the upstream (2, 19 and $23 \mu \mathrm{g} \mathrm{L}^{-1}$ for respectively Sept 2012, May 2013 and Feb 2014) and the downstream end members ( $2 \mu \mathrm{g} \mathrm{L}^{-1}$; data not shown) indicating no important reactivity.

(2) Redox conditions can vary. Particles pass through or settle temporarily in oxygendepleted zones like the MTZ (according to the season, SYVEL network), the fluid mud or the sediment. In MTZ, fluid mud, and top sediment, oscillations of redox conditions are 
controlled by resuspension and deposition events, mostly driven by tidal cycles (period of oscillation of $6 \mathrm{~h}$ ) or episodic wind events. Once particles settle and consolidate in a mudflat, redox oscillations become controlled by macrofaunal burrowing. As a result, the redox oscillation period increases up to few weeks (Wheatcroft et al., 1990; Meysman et al., 2003, 2008). Differentiating both processes is beyond the scope of this study but they probably involve different chemical species according to the thermodynamic ladder of early diagenetic primary reactions (Aller, 2004). For short anoxic periods, nitrate and Mn reduction would control redox processes while for longer anoxic periods (few weeks), Fe reduction would be the principal reaction.

Comparison of ascorbate-extracted metals between SPM and bottom sediment (at $20 \mathrm{~cm}$ depth; only available for February 2014) shows a decrease of $\mathrm{Mn}_{\mathrm{asc}}$ content between 470 and $770 \mathrm{mg} \mathrm{kg}^{-1}$ (Fig. 3a), and a decrease of $\mathrm{Fe}_{\text {asc }}$ content between 0.17 and $0.55 \% \mathrm{w} / \mathrm{w}$ (Fig. 3c). These losses correspond to long-term transformations since bottom particles have been deposited more than 50 years ago $\left({ }^{210} \mathrm{~Pb}\right.$ dating, Thibault de Chanvalon et al, this issue). Figure $6 \mathrm{~b}$ shows that $\mathrm{Mn}_{\text {asd }} / \mathrm{Al}$ and $\mathrm{Mn} / \mathrm{Al}$ ratios are strongly correlated in the sediment $\left(\mathrm{r}^{2}=\right.$ 0.94, slope $=1$ ). It clearly demonstrates that the $\mathrm{Mn}_{\text {asc }}$ loss corresponds to a net $\mathrm{Mn}$ loss (removal to the water column). Reciprocally, the $\mathrm{Mn}_{\text {asc }}$ enrichment (compared to $\mathrm{SPM} \mathrm{Mn}_{\text {asc }}$ content) visible at $5 \mathrm{~cm}$ depth in Fig. 3a corresponds to a $\mathrm{Mn}$ enrichment (Fig 6b). Contrastingly, estuarine SPM do not line up with sediment samples (Fig. 6b) and present a variable $\mathrm{Mn}_{\text {asc }} / \mathrm{Al}$ enrichment. This is despite a nearly constant $\mathrm{Mn} / \mathrm{Al}$ value that could be explained by a phase switch from a part of $\mathrm{Mn}_{\text {asc }}$ to a non-ascorbate-sensitive solid phase occurring when particles settle (or in the very first moment after deposition). Therefore, 2 reactions are necessary to explain the $\mathrm{Mn}_{\text {asc }}$ during settling (1) an unknown fast 
transformation from $\mathrm{Mn}_{\mathrm{asc}}$ to another $\mathrm{Mn}$ phase at the sediment surface or in the MTZ and (2) a loss of $\mathrm{Mn}_{\mathrm{asc}}$ (generating also a $\mathrm{Mn}$ loss) on the long term, probably due to the reductive dissolution of Mn oxides. After this second reaction, a part of dissolved atoms leaves the sediment by diffusion and generates a loss of $\mathrm{Mn}_{\text {asc }}$ and $\mathrm{Mn}$ while another part precipitates into $\mathrm{Mn}$ oxides which generates a gain of both $\mathrm{Mn}_{\text {asc }}$ and $\mathrm{Mn}$ (as observed at $0.5 \mathrm{~cm}$ depth; Fig. 3a). It is striking that no transformation of $\mathrm{Mn}_{\text {asc }}$ to a non-ascorbate-sensitive phase is observed for deep sediment (Fig. 6b), as expected if a third part of the dissolved atoms precipitates within the anoxic sediment (e.g. in a carbonate/sulfidic form).

Figure 6a shows that in February 2014, the $\mathrm{Fe}_{\mathrm{asc}}$ loss corresponds to a net loss of Fe for particles $\left(\mathrm{r}^{2}=0.52, \mathrm{p}<10^{-5}\right)$ due to reductive dissolution of Fe oxides followed by diffusion toward the water column. The relation is much less clear for Fe than for Mn probably because of the presence of numerous ascorbate-extractable Fe phases (e.g. Hyacinthe and Van Cappellen, 2004) and they represent only 8 to $20 \%$ of the total Fe content. Moreover, transformation of $\mathrm{Fe}_{\text {asc }}$ into a non-ascorbate-sensitive form in anoxic sediment (such as $\mathrm{FeS}_{2}$ ) would also scatter the data. To sum up, comparison of total and ascorbate-extracted Fe and Mn demonstrates that chemical transformations during early diagenesis are likely to strongly modify metals content and $\mathrm{Fe} / \mathrm{Al}$ and $\mathrm{Mn} / \mathrm{Al}$ ratios as observed in SPM end members.

\subsection{Particles transfer from sediment to MTZ}

$\mathrm{Fe} / \mathrm{Al}$ and $\mathrm{Mn} / \mathrm{Al}$ ratios in the MTZ are roughly similar to elementary ratios of surface sediments (Fig. S4) which would indicate an intensive mixing of particles from both the MTZ 
and surface sediments. However, these ratios are also similar to riverine particles ratios, preventing their use to characterize the transfer of sediment particles to the MTZ.

The study of REE signatures may help to deal with this issue since $\mathrm{Ce}$ and $\mathrm{Eu}$ are the only REE sensitive to redox conditions. Cerium (II) oxidation can be produced by the available oxygen within the water column (e.g. Elderfield et al., 1981; Dubinin et al., 2013) or by $\mathrm{MnO}_{2}$ (Ohta and Kawabe, 2001) while Ce (IV) reduction can be generated by low redox potentials (Elderfield and Sholkovitz, 1987) and/or acidic conditions (Elderfield et al., 1990; Xu and Han, 2009). The high values of Ce anomalies in SPM (Fig. 5a) are often associated with Mn oxides coating under oxic conditions (Sholkovitz et al., 1994). The large data spread (Fig. 5a) and the non correlation of $\mathrm{Ce} / \mathrm{La}$ with $\mathrm{Fe} / \mathrm{Al}$ or $\mathrm{Mn} / \mathrm{Al}$ (data not shown) indicate as many scenarios of different redox stages. Contrastingly, a specific process maintains a constant and low Ce/La ratio in the sediment and MTZ (Fig. 5a). In fact, the dissolution of Ce oxides in the suboxic sediment or in the acidic conditions produced by aerobic respiration may lead to the low $\mathrm{Ce} / \mathrm{La}$ ratio observed in the sediment (Fig. 5a). However, the constant Ce/La ratio could also originate from the sedimentary enrichment of REE (Fig. 5d) and the subsequent mass dilution of positive Ce anomalies due to particle coating. As observed by Elderfield and Sholkovitz (1987), Sholkovitz et al. (1989) or Haley et al. (2004), an important upward flux of dissolved REE with low Ce/La ratio may precipitate simultaneously with Mn oxides (German et al., 1991; Sholkovitz, 1992) and may also explain the observed sediment enrichment (Fig. $5 d)$.

$\mathrm{Eu} / \mathrm{Sm}$ decreases when SPM concentration increases reaching a crustal value (close to 1) in the sediment (Fig. 5b). Theoretically, $\mathrm{Eu}$ (III) reduction into $\mathrm{Eu}$ (II) requires temperatures typical of hydrothermal activities (Sverjensky, 1984; Dubinin, 2004), which is unlikely to 
occur in the Loire Estuary. However, several studies on low temperature processes report similar positive Eu anomalies in particles from Chesapeake Bay (Hannigan et al., 2010), Changjiang River and Estuary (Zhang et al., 1998; Yang et al., 2002, 2003; Xu et al., 2009), Loire River SPM (Négrel and Grosbois, 1999), and in geological aged material (Ogihara, 1999; Kidder et al., 2003; Murthy et al., 2004; Leybourne et al., 2006). Moreover Zhang et al. (1998) and Gerard et al. (2003) in the Changjiang and Amazon Basin respectively, found also a systematic high $\mathrm{Eu} / \mathrm{Sm}$ ratio in SPM and low $\mathrm{Eu} / \mathrm{Sm}$ in bedload sediment. The preferential weathering mobilization of $\mathrm{Eu}(\mathrm{II})$ available in host rocks (Leybourne and Johannesson, 2008) and subsequent precipitation with ascorbate sensitive Fe oxides (Fig. 5c) could explain the high $\mathrm{Eu} / \mathrm{Sm}$ ratio in the SPM. The diagenetic remobilisation of Fe oxides and associated $\mathrm{Eu}$ may induce a decrease in $\mathrm{Eu} / \mathrm{Sm}$ ratios.

Concluding, the similarity of REE signatures between sediment and MTZ supports the surface sediment exchange scenario. However, contrastingly to $\mathrm{Fe}$ behaviour, diagenetic transformations are rapidly hidden by $\mathrm{Ce}$ and $\mathrm{Eu}$ reactivity in oxic conditions leading to similar upstream and downstream signatures.

\subsection{Long term SPM behaviour}

While particles move progressively downstream, their residence time within the estuary increases and chemical transformations progress. Therefore, along a salinity gradient, salinity potentially traces the progressive transformation of bulk SPM. Figure 7 illustrates particles ageing through the Loire Estuary: as salinity increases, the number of redox oscillations undergone by particles increases whiles the Fe content decreases. However, such Fe 
decreasing is only visible for high water discharge conditions, when the salinity gradient is pushed outside the Loire Estuary and when SPM sampled are older (i.e. endured more redox oscillations). This specificity of high flow samples thus indicates a long term process of estuarine transformation (more than the average residence time of particles inside the inner estuary; i.e., several years). Moreover, during floods, energy may be sufficient to suspend a thicker layer of sediment impoverished in metallic oxides (i.e. ascorbate extracted Fe and Mn, Fig. 3a and 3c). This would lead to the same results as above: low Fe/Al and Mn/Al.

The overall transformation due to redox oscillations during estuarine transfer can be estimated by the ratio between downstream (Fe/Al $=0.4780 \pm 0.0005)$ and upstream $(\mathrm{Fe} / \mathrm{Al}=0.5575 \pm 0.0015) \quad$ end-members $\quad$ (Fig. 2). This shows a loss of $14.3 \%$ $\left(\mathrm{Fe}_{\text {downstream }} / \mathrm{Fe}_{\text {upstream }}=85.7 \%\right)$ of SPM Fe content. Assuming that terrigenous particles have an $\mathrm{Al}$ content of $10 \% \mathrm{w} / \mathrm{w}$ and that reactive $\mathrm{Fe}$ can be described as $\mathrm{Fe}(\mathrm{OH})_{3}$, estuarine transfer could represent a loss of $1.52 \%$ of the total mass of terrigenous particles transiting through the Loire Estuary. This value, is in good agreement with the $2 \%$ loss estimated by Raiswell (2006). If Mn loss occurred as well, it is however hidden by the variations of $\mathrm{Mn} / \mathrm{Al}$ in riverine SPM. If $\mathrm{Mn} / \mathrm{Al}$ ratio was conservative during the transfer across the estuary, the coastal $\mathrm{Mn} / \mathrm{Al}$ ratio would correspond to the mean of $\mathrm{Mn} / \mathrm{Al}$ ratios of the inflowing riverine particles, and yet, the Mn/Al ratios for coastal SPM of May 2013 are lower than most of the riverine ratios (Fig. 2). This mismatch is probably induced by a decrease of $\mathrm{Mn} / \mathrm{Al}$ ratio in particles as they go across the estuary.

Since the studied particles have a similar source defined by the riverine Fe/Al ratio, the comparison between $\mathrm{Fe} / \mathrm{Al}$ ratio after redox oscillations during estuarine transfer $(\mathrm{Fe} / \mathrm{Al}=0.478, \mathrm{Fe}$ loss of $14.3 \%)$ and after early diagenesis during burial $(\mathrm{Fe} / \mathrm{Al}=0.52, \mathrm{Fe}$ loss 
of $6.7 \%$ ) shows that estuarine transfer induces more important metal loss than sedimentary burial. Since SPM probably undergoes more redox oscillations, this comparison shows that the number of redox oscillations is more important than time span under anoxic conditions. It is probably because during short anoxic oscillations, sulfidic conditions cannot install and efficiently trap Fe as FeS.

\section{Conclusion}

The iron cycle strongly depends on estuarine processes: from Nantes to the coast, particles lose $14.3 \%$ of their total Fe content. This composition change is mostly a loss of poorly crystalline Fe oxides and can be explained by the redox oscillations endured by particles during their transport through the estuary, especially during their temporary settling. However redox transformations are not limited to the inner estuary and an important part of Fe losses can be attributed to river-dominated margins (RiOMar), although further work is necessary for assessing RiOMar relative importance. Manganese transformations are largely controlled by Mn oxides of which the input is seasonally dependant. The degree of crystallinity of Mn oxides seems to increase as soon as they settle, indicating a specific and not yet identified transformation occurring in the MTZ. Finally, REE are enriched in sediment and MTZ by a sedimentary source which may mask other possible $\mathrm{Eu}$ and/or Ce anomalies. While more work is necessary to confirm this speculation, Eu enrichment is likely due to Eu incorporation within Fe oxides. 


\section{Acknowledgment}

This study is part of the RS2E - OSUNA project funded by the Région Pays de la Loire. The authors want to thank the associate editor and reviewers for their valuable suggestions to improve this manuscript. Thanks also to Cyrille Guindir, Clément Chauvin, Eric Bénéteau, Emmanuelle Rozuel, Dominique Auger, Sylvette Crochet, Bastien Thomas and the N/O Thalia crew for their technical help and to Meryem Mojtahid for English corrections. 
Abril, G., Commarieu, M.-V., Etcheber, H., Deborde, J., Deflandre, B., Živađinović, M. K., Chaillou, G. and Anschutz, P.: In vitro simulation of oxic/suboxic diagenesis in an estuarine fluid mud subjected to redox oscillations, Estuar. Coast. Shelf Sci., 88(2), 279-291, doi:10.1016/j.ecss.2010.04.003, 2010.

Abril, G., Etcheber, H., Le Hir, P., Bassoullet, P., Boutier, B. and Frankignoulle, M.: Oxic/anoxic oscillations and organic carbon mineralization in an estuarine maximum turbidity zone (The Gironde, France), Limnol. Oceanogr., 44(5), 1304-1315, doi:10.4319/lo.1999.44.5.1304, 1999.

Abril, G., Nogueira, M., Etcheber, H., Cabeçadas, G., Lemaire, E. and Brogueira, M. .: Behaviour of Organic Carbon in Nine Contrasting European Estuaries, Estuar. Coast. Shelf Sci., 54(2), 241-262, doi:10.1006/ecss.2001.0844, 2002.

Abril, G., Riou, S. A., Etcheber, H., Frankignoulle, M., de Wit, R. and Middelburg, J. J.: Transient, Tidal Time-scale, Nitrogen Transformations in an Estuarine Turbidity MaximumFluid Mud System (The Gironde, South-west France), Estuar. Coast. Shelf Sci., 50(5), $703-$ 715, doi:10.1006/ecss.1999.0598, 2000.

Aller, R. C.: The Effects of Macrobenthos on Chemical Properties of Marine Sediment and Overlying Water, in Animal-Sediment Relations, edited by P. L. McCall and M. J. S. Tevesz, pp. 53-102, Springer US. [online] Available from: http://link.springer.com/chapter/10.1007/978-1-4757-1317-6_2 (Accessed 22 August 2014), 1982.

Aller, R. C.: Mobile deltaic and continental shelf muds as suboxic, fluidized bed reactors, Mar. Chem., 61(3-4), 143-155, doi:10.1016/S0304-4203(98)00024-3, 1998.

Aller, R. C.: Conceptual models of early diagenetic processes: The muddy seafloor as an unsteady, batch reactor, J. Mar. Res., 62(6), 815-835, doi:10.1357/0022240042880837, 2004.

Aller, R. C. and Blair, N. E.: Carbon remineralization in the Amazon-Guianas tropical mobile mudbelt: A sedimentary incinerator, Cont. Shelf Res., 26(17-18), 2241-2259, doi:10.1016/j.csr.2006.07.016, 2006.

Andrieux-Loyer, F., Philippon, X., Bally, G., Kérouel, R., Youenou, A. and Le Grand, J.: Phosphorus dynamics and bioavailability in sediments of the Penzé Estuary (NW France): in relation to annual P-fluxes and occurrences of Alexandrium Minutum, Biogeochemistry, 88(3), 213-231, doi:10.1007/s10533-008-9199-2, 2008.

Anschutz, P., Dedieu, K., Desmazes, F. and Chaillou, G.: Speciation, oxidation state, and reactivity of particulate manganese in marine sediments, Chem. Geol., 218(3-4), 265-279, doi:10.1016/j.chemgeo.2005.01.008, 2005.

Audry, S., Blanc, G., Schäfer, J., Chaillou, G. and Robert, S.: Early diagenesis of trace metals $(\mathrm{Cd}, \mathrm{Cu}, \mathrm{Co}, \mathrm{Ni}, \mathrm{U}, \mathrm{Mo}$, and $\mathrm{V})$ in the freshwater reaches of a macrotidal estuary, Geochim. Cosmochim. Acta, 70(9), 2264-2282, doi:10.1016/j.gca.2006.02.001, 2006.

Audry, S., Blanc, G., Schäfer, J. and Robert, S.: Effect of estuarine sediment resuspension on early diagenesis, sulfide oxidation and dissolved molybdenum and uranium distribution in the Gironde estuary, France, Chem. Geol., 238(3-4), 149-167, doi:10.1016/j.chemgeo.2006.11.006, 2007. 
Banner, J. L., Hanson, G. and Meyers, W.: Rare earth element and Nd isotopic variations in regionally extensive dolomites from the Burlington-Keokuk Formation (Mississippian): Implications for REE mobility during carbonate diagenesis, J. Sediment. Res., 58(3), 1988.

Benyoucef, I.: Télédétection visible proche-infrarouge de la distribution spatio-temporelle du microphytobenthos estuarien, Ph.D. thesis, Université de Nantes, 4 August., 2014.

Benyoucef, I., Blandin, E., Lerouxel, A., Jesus, B., Rosa, P., Méléder, V., Launeau, P. and Barillé, L.: Microphytobenthos interannual variations in a north-European estuary (Loire estuary, France) detected by visible-infrared multispectral remote sensing, Estuar. Coast. Shelf Sci., 136, 43-52, doi:10.1016/j.ecss.2013.11.007, 2014.

Billen, G., Cauwet, G., Dessery, S., Meybeck, M. and Somville, M.: Origines et comportement du carbone organique dans l'estuaire de la Loire, Rapp. ProcŠs-Verbaux RèunionsConseil Int. Pour Explot. Mer, 186, 375-391, 1986.

Cauwet, G. and Meybeck, M.: Seasonal fluctuations of carbon levels in a temperate river, Loire river (France)., in Transport of Carbon and Minerals in World Major Rivers. Part IV. Mitt. Geol. Paltiont., vol. 64, pp. 359-357, Univ. Hamburg., 1987.

Chiffoleau, J.-F., Cossa, D., Auger, D. and Truquet, I.: Trace metal distribution, partition and fluxes in the Seine estuary (France) in low discharge regime, Mar. Chem., 47(2), 145-158, doi:10.1016/0304-4203(94)90105-8, 1994.

Church, T. M.: Biogeochemical factors influencing the residence time of microconstituents in a large tidal estuary, Delaware Bay, Mar. Chem., 18(2-4), 393-406, doi:10.1016/03044203(86)90020-4, 1986.

Ciffroy, P., Garnier, J.-M. and Benyahya, L.: Kinetic partitioning of Co, Mn, Cs, Fe, Ag, Zn and $\mathrm{Cd}$ in fresh waters (Loire) mixed with brackish waters (Loire estuary): experimental and modelling approaches, Mar. Pollut. Bull., 46(5), 626-641, doi:10.1016/S0025326X(02)00517-9, 2003a.

Ciffroy, P., Reyss, J.-L. and Siclet, F.: Determination of the residence time of suspended particles in the turbidity maximum of the Loire estuary by $7 \mathrm{Be}$ analysis, Estuar. Coast. Shelf Sci., 57(4), 553-568, doi:10.1016/S0272-7714(02)00339-6, 2003 b.

Crouzet, P.: L’eutrophisation de la Loire, Water Supply, (1), 131-144, 1983.

Dalrymple, R. W., Zaitlin, B. A. and Boyd, R.: Estuarine facies models: conceptual basis and stratigraphic implications: perspective, J. Sediment. Res., 62(6), 1992.

DREAL Pays-de-Loire: hydroweb, [online] Available from: http://www.hydro.eaufrance.fr/presentation/procedure.php (Accessed 30 July 2015), 1994.

Dubinin, A., Sval'nov, V., Berezhnaya, E., Rimskaya-Korsakova, M. and Demidova, T.: Geochemistry of trace and minor elements in sediments and manganese micronodules from the Angola Basin, Lithol. Miner. Resour., 48(3), 175-197, 2013.

Dubinin, A. V.: Geochemistry of rare earth elements in the ocean, Lithol. Miner. Resour., 39(4), 289-307, 2004. 
Elderfield, H., Hawkesworth, C., Greaves, M. and Calvert, S.: Rare earth element geochemistry of oceanic ferromanganese nodules and associated sediments, Geochim. Cosmochim. Acta, 45(4), 513-528, 1981.

Elderfield, H. and Sholkovitz, E. R.: Rare earth elements in the pore waters of reducing nearshore sediments, Earth Planet. Sci. Lett., 82(3-4), 280-288, doi:10.1016/0012821X(87)90202-0, 1987.

Elderfield, H., Upstill-Goddard, R. and Sholkovitz, E. R.: The rare earth elements in rivers, estuaries, and coastal seas and their significance to the composition of ocean waters, Geochim. Cosmochim. Acta, 54(4), 971-991, 1990.

Escoube, R., Rouxel, O. J., Sholkovitz, E. and Donard, O. F. X.: Iron isotope systematics in estuaries: The case of North River, Massachusetts (USA), Geochim. Cosmochim. Acta, 73(14), 4045-4059, doi:10.1016/j.gca.2009.04.026, 2009.

Figueres, G., Martin, J., Meybeck, M. and Seyler, P.: A comparative study of mercury contamination in the Tagus Estuary (Portugal) and major French Estuaries (Gironde, Loire, Rhône), Estuar. Coast. Shelf Sci., 20(2), 183-203, 1985.

Freslon, N., Bayon, G., Toucanne, S., Bermell, S., Bollinger, C., Chéron, S., Etoubleau, J., Germain, Y., Khripounoff, A., Ponzevera, E. and Rouget, M.-L.: Rare earth elements and neodymium isotopes in sedimentary organic matter, Geochim. Cosmochim. Acta, 140, 177198, doi:10.1016/j.gca.2014.05.016, 2014.

Froelich, P. N., Klinkhammer, G. P., Bender, M. L., Luedtke, N. A., Heath, G. R., Cullen, D., Dauphin, P., Hammond, D., Hartman, B. and Maynard, V.: Early oxidation of organic matter in pelagic sediments of the eastern equatorial Atlantic: suboxic diagenesis, Geochim. Cosmochim. Acta, 43(7), 1075-1090, doi:10.1016/0016-7037(79)90095-4, 1979.

Gerard, M., Seyler, P., Benedetti, M. F., Alves, V. P., Boaventura, G. R. and Sondag, F.: Rare earth elements in the Amazon basin, Hydrol. Process., 17(7), 1379-1392, doi:10.1002/hyp.1290, 2003.

German, C. R., Holliday, B. P. and Elderfield, H.: Redox cycling of rare earth elements in the suboxic zone of the Black Sea, Geochim. Cosmochim. Acta, 55(12), 3553-3558, doi:10.1016/0016-7037(91)90055-A, 1991.

Gernez, P., Lafon, V., Lerouxel, A., Curti, C., Lubac, B., Cerisier, S. and Barillé, L.: Toward Sentinel-2 High Resolution Remote Sensing of Suspended Particulate Matter in Very Turbid Waters: SPOT4 (Take5) Experiment in the Loire and Gironde Estuaries, Remote Sens., 7(8), 9507-9528, doi:10.3390/rs70809507, 2015.

Gorse, laureline, Coynel, A. and Etcheber, H.: Analyse multi-proxies des eaux du bassin versant de la Loire inférieure et estuarienne, 2010.

Grandjean, P., Cappetta, H., Michard, A. and Albarede, F.: The assessment of REE patterns and $143 \mathrm{Nd} / 144 \mathrm{Nd}$ ratios in fish remains, Earth Planet. Sci. Lett., 84(2-3), 181-196, 1987.

Grosbois, C., Négrel, P., Grimaud, D. and Fouillac, C.: An overview of dissolved and suspended matter fluxes in the Loire river basin: natural and anthropogenic inputs, Aquat. Geochem., 7(2), 81-105, 2001. 
Haley, B. A., Klinkhammer, G. P. and McManus, J.: Rare earth elements in pore waters of marine sediments, Geochim. Cosmochim. Acta, 68(6), 1265-1279, doi:10.1016/j.gca.2003.09.012, 2004.

Hannigan, R., Dorval, E. and Jones, C.: The rare earth element chemistry of estuarine surface sediments in the Chesapeake Bay, Chem. Geol., 272(1-4), 20-30, doi:10.1016/j.chemgeo.2010.01.009, 2010.

Hannigan, R. E. and Sholkovitz, E. R.: The development of middle rare earth element enrichments in freshwaters: weathering of phosphate minerals, Chem. Geol., 175(3-4), 495508, doi:10.1016/S0009-2541(00)00355-7, 2001.

Hyacinthe, C., Bonneville, S. and Van Cappellen, P.: Reactive iron(III) in sediments: Chemical versus microbial extractions, Geochim. Cosmochim. Acta, 70(16), 4166-4180, doi:10.1016/j.gca.2006.05.018, 2006.

Hyacinthe, C. and Van Cappellen, P.: An authigenic iron phosphate phase in estuarine sediments: composition, formation and chemical reactivity, Mar. Chem., 91(1-4), 227-251, doi:10.1016/j.marchem.2004.04.006, 2004.

Johannesson, K. H., Lyons, W. B., Yelken, M. A., Gaudette, H. E. and Stetzenbach, K. J.: Geochemistry of the rare-earth elements in hypersaline and dilute acidic natural terrestrial waters: Complexation behavior and middle rare-earth element enrichments, Chem. Geol., 133(1-4), 125-144, doi:10.1016/S0009-2541(96)00072-1, 1996.

Johannesson, K. H., Tang, J., Daniels, J. M., Bounds, W. J. and Burdige, D. J.: Rare earth element concentrations and speciation in organic-rich blackwaters of the Great Dismal Swamp, Virginia, USA, Chem. Geol., 209(3-4), 271-294, doi:10.1016/j.chemgeo.2004.06.012, 2004.

Jouanneau, J. M., Weber, O., Cremer, M. and Castaing, P.: Fine-grained sediment budget on the continental margin of the Bay of Biscay, Deep Sea Res. Part II Top. Stud. Oceanogr., 46(10), 2205-2220, 1999.

Kidder, D. L., Krishnaswamy, R. and Mapes, R. H.: Elemental mobility in phosphatic shales during concretion growth and implications for provenance analysis, Chem. Geol., 198(3-4), 335-353, doi:10.1016/S0009-2541(03)00036-6, 2003.

Kostka, J. E. and Luther, G. W.: Partitioning and speciation of solid phase iron in saltmarsh sediments, Geochim. Cosmochim. Acta, 58(7), 1701-1710, doi:10.1016/00167037(94)90531-2, 1994.

Kraepiel, A. M., Chiffoleau, J.-F., Martin, J.-M. and Morel, F. M.: Geochemistry of trace metals in the Gironde estuary, Geochim. Cosmochim. Acta, 61(7), 1421-1436, 1997.

Lalonde, K., Mucci, A., Ouellet, A. and Gélinas, Y.: Preservation of organic matter in sediments promoted by iron, Nature, 483(7388), 198-200, doi:10.1038/nature10855, 2012.

Lam, P. J., Ohnemus, D. C. and Marcus, M. A.: The speciation of marine particulate iron adjacent to active and passive continental margins, Geochim. Cosmochim. Acta, 80, 108-124, doi:10.1016/j.gca.2011.11.044, 2012. 
Lawrence, M. G. and Kamber, B. S.: The behaviour of the rare earth elements during estuarine mixing-revisited, Mar. Chem., 100(1-2), 147-161, doi:10.1016/j.marchem.2005.11.007, 2006.

Le Douarec, P.: L'intrusion saline dans l'estuaire de la Loire., Université de Nantes., 1978.

Leybourne, M. I., Clark, I. D. and Goodfellow, W. D.: Stable isotope geochemistry of ground and surface waters associated with undisturbed massive sulfide deposits; constraints on origin of waters and water-rock reactions, Chem. Geol., 231(4), 300-325, doi:10.1016/j.chemgeo.2006.02.004, 2006.

Leybourne, M. I. and Johannesson, K. H.: Rare earth elements (REE) and yttrium in stream waters, stream sediments, and Fe-Mn oxyhydroxides: Fractionation, speciation, and controls over REE $+Y$ patterns in the surface environment, Geochim. Cosmochim. Acta, 72(24), 59625983, doi:10.1016/j.gca.2008.09.022, 2008.

Lim, D., Jung, H. S. and Choi, J. Y.: REE partitioning in riverine sediments around the Yellow Sea and its importance in shelf sediment provenance, Mar. Geol., 357, 12-24, doi:10.1016/j.margeo.2014.07.002, 2014.

Lyons, T. W. and Severmann, S.: A critical look at iron paleoredox proxies: New insights from modern euxinic marine basins, Geochim. Cosmochim. Acta, 70(23), 5698-5722, doi:10.1016/j.gca.2006.08.021, 2006.

Manickam, S., Barbaroux, L. and Ottmann, F.: Composition and mineralogy of suspended sediment in the fluvio-estuarine zone of the Loire River, France, Sedimentology, 32(5), 721741, doi:10.1111/j.1365-3091.1985.tb00484.x, 1985.

Martin, J. H. and Fitzwater, S. E.: Iron deficiency limits phytoplankton growth in the northeast Pacific subarctic, Nature, 331(6154), 341-343, doi:10.1038/331341a0, 1988.

Meybeck, M., Cauwet, G., Dessery, S., Somville, M., Gouleau, D. and Billen, G.: Nutrients (organic C, P, N, Si) in the eutrophic River Loire (France) and its estuary, Estuar. Coast. Shelf Sci., 27(6), 595-624, doi:10.1016/0272-7714(88)90071-6, 1988.

Meysman, F. J. R., Boudreau, B. P. and Middelburg, J. J.: Relations between local, nonlocal, discrete and continuous models of bioturbation, J. Mar. Res., 61(3), 391-410, doi:10.1357/002224003322201241, 2003.

Meysman, F. J. R., Malyuga, V. S., Boudreau, B. P. and Middelburg, J. J.: A generalized stochastic approach to particle dispersal in soils and sediments, Geochim. Cosmochim. Acta, 72(14), 3460-3478, doi:10.1016/j.gca.2008.04.023, 2008.

Migniot, C.: Bilan de l'hydrologie et de l'hydrosédimentaire de l'estuaire de la Loire au cours des deux dernières décennies, Association pour la protection de l'environnement de l'estuaire de la Loire et Port autonome de Nantes-Saint Nazaire. [online] Available from: http://oaidoc.eau-loire-bretagne.fr/exl-doc/doc00004390.pdf, 1993.

Minaudo, C., Meybeck, M., Moatar, F., Gassama, N. and Curie, F.: Eutrophication mitigation in rivers: 30 years of trends in spatial and seasonal patterns of biogeochemistry of the Loire River (1980-2012), Biogeosciences, 12(8), 2549-2563, doi:10.5194/bg-12-2549-2015, 2015. 
Moore, R., Burton, J., Williams, P. L. and Young, M.: The behaviour of dissolved organic material, iron and manganese in estuarine mixing, Geochim. Cosmochim. Acta, 43(6), 919926, 1979.

Morris, A., Mantoura, R., Bale, A. and Howland, R.: Very low salinity regions of estuaries: important sites for chemical and biological reactions, 1978.

Morris, A. W., Bale, A. J., Howland, R. J. M., Loring, D. H. and Rantala, R. T. T.: Controls of the chemical composition of particle populations in a macrotidal estuary (Tamar Estuary, U.K.), Cont. Shelf Res., 7(11-12), 1351-1355, doi:10.1016/0278-4343(87)90039-2, 1987.

Murthy, R., Kidder, D., Mapes, R. and Hannigan, R.: Rare-earth element chemistry of Mississippianage phosphate nodules in the Fayetteville Shale of Oklahoma and Arkansas, Environ. Geosci., 11(2), 99-111, 2004.

Négrel, P.: Multi-element Chemistry of Loire Estuary Sediments: Anthropogenic vs. Natural Sources, Estuar. Coast. Shelf Sci., 44(4), 395-410, 1997.

Négrel, P. and Grosbois, C.: Changes in chemical and $87 \mathrm{Sr} / 86 \mathrm{Sr}$ signature distribution patterns of suspended matter and bed sediments in the upper Loire river basin (France), Chem. Geol., 156(1-4), 231-249, doi:10.1016/S0009-2541(98)00182-X, 1999.

Ogihara, S.: Geochemical characteristics of phosphorite and carbonate nodules from the Miocene Funakawa Formation, western margin of the Yokote Basin, northeast Japan, Sediment. Geol., 125(1), 69-82, 1999.

Ohta, A. and Kawabe, I.: REE(III) adsorption onto $\mathrm{Mn}$ dioxide $(\delta$-MnO2) and $\mathrm{Fe}$ oxyhydroxide: $\mathrm{Ce}(\mathrm{III})$ oxidation by $\delta$-MnO2, Geochim. Cosmochim. Acta, 65(5), 695-703, doi:10.1016/S0016-7037(00)00578-0, 2001.

Poulton, S. W. and Raiswell, R.: The low-temperature geochemical cycle of iron: from continental fluxes to marine sediment deposition, Am. J. Sci., 302(9), 774-805, 2002.

Raiswell, R.: Towards a global highly reactive iron cycle, J. Geochem. Explor., 88(1-3), 436439, doi:10.1016/j.gexplo.2005.08.098, 2006.

Raiswell, R.: Iron Transport from the Continents to the Open Ocean: The Aging-Rejuvenation Cycle, Elements, 7(2), 101-106, doi:10.2113/gselements.7.2.101, 2011.

Raiswell, R., Vu, H. P., Brinza, L. and Benning, L. G.: The determination of labile Fe in ferrihydrite by ascorbic acid extraction: methodology, dissolution kinetics and loss of solubility with age and de-watering, Chem. Geol., 278(1), 70-79, 2010.

Rantala, R. T. T. and Loring, D. H.: Determination of Lithium in the NRCC Marine Sediments: MESS-1, BCSS-1, PACS-1 and the NIST River Sediment: SRM 2704, Geostand. Newsl., 14(3), 475-476, 1990.

Regnier, P. and Wollast, R.: Distribution of trace metals in suspended matter of the Scheldt estuary, Mar. Chem., 43(1-4), 3-19, doi:10.1016/0304-4203(93)90212-7, 1993. 
Robert, S., Blanc, G., Schäfer, J., Lavaux, G. and Abril, G.: Metal mobilization in the Gironde Estuary (France): the role of the soft mud layer in the maximum turbidity zone, Mar. Chem., 87(1-2), 1-13, doi:10.1016/S0304-4203(03)00088-4, 2004.

Saliot, A., Tronczynski, J., Scribe, P. and Letolle, R.: The application of isotopic and biogeochemical markers to the study of the biochemistry of organic matter in a macrotidal estuary, the Loire, France, Estuar. Coast. Shelf Sci., 27(6), 645-669, doi:10.1016/02727714(88)90073-X, 1988.

Sholkovitz, E. R.: The flocculation of dissolved $\mathrm{Fe}, \mathrm{Mn}, \mathrm{Al}, \mathrm{Cu}, \mathrm{Ni}, \mathrm{Co}$ and $\mathrm{Cd}$ during estuarine mixing, Earth Planet. Sci. Lett., 41(1), 77-86, doi:10.1016/0012-821X(78)90043-2, 1978.

Sholkovitz, E. R.: Chemical evolution of rare earth elements: fractionation between colloidal and solution phases of filtered river water, Earth Planet. Sci. Lett., 114(1), 77-84, doi:10.1016/0012-821X(92)90152-L, 1992.

Sholkovitz, E. R., Landing, W. M. and Lewis, B. L.: Ocean particle chemistry: The fractionation of rare earth elements between suspended particles and seawater, Geochim. Cosmochim. Acta, 58(6), 1567-1579, doi:10.1016/0016-7037(94)90559-2, 1994.

Sholkovitz, E. R., Piepgras, D. J. and Jacobsen, S. B.: The pore water chemistry of rare earth elements in Buzzards Bay sediments, Geochim. Cosmochim. Acta, 53(11), 2847-2856, doi:10.1016/0016-7037(89)90162-2, 1989.

SOGREAH: développement et éxploitation d'un modèle hydrosédimentaire en trois dimensions sur l'estuaire de la Loire, SOGREAH consultants. [online] Available from: http://www.loire-

estuaire.org/upload/espace/1/outils/modeles_hydro_sedimentaires/rapport_sogreah_R10.pdf (Accessed 30 July 2015), 2010.

Sverjensky, D. A.: Europium redox equilibria in aqueous solution, Earth Planet. Sci. Lett., 67(1), 70-78, 1984.

Tang, J. and Johannesson, K. H.: Ligand extraction of rare earth elements from aquifer sediments: Implications for rare earth element complexation with organic matter in natural waters, Geochim. Cosmochim. Acta, 74(23), 6690-6705, doi:10.1016/j.gca.2010.08.028, 2010 .

Thibault de Chanvalon, A., Metzger, E., Mouret, A., Cesbron, F., Knoery, J., Rozuel, E., Launeau, P., Nardelli, M. P., Jorissen, F. J. and Geslin, E.: Two-dimensional distribution of living benthic foraminifera in anoxic sediment layers of an estuarine mudflat (Loire estuary, France), Biogeosciences, 12(20), 6219-6234, doi:10.5194/bg-12-6219-2015, 2015.

Thibault de Chanvalon, A., Mouret, A., Geslin, E., Knoery, J., Péron, O. and Metzger, E.: Manganese, iron and phosphorus cycling in an estuarine mudflat sediment, Loire, France., J. Sea Res., submitted.

Thompson, A., Chadwick, O. A., Rancourt, D. G. and Chorover, J.: Iron-oxide crystallinity increases during soil redox oscillations, Geochim. Cosmochim. Acta, 70(7), 1710-1727, doi:10.1016/j.gca.2005.12.005, 2006. 
Trefry, J. H. and Presley, B. J.: Manganese fluxes from Mississippi Delta sediments, Geochim. Cosmochim. Acta, 46(10), 1715-1726, doi:10.1016/0016-7037(82)90112-0, 1982.

Turner, A.: Trace Metal Contamination in Sediments from U.K. Estuaries: An Empirical Evaluation of the Role of Hydrous Iron and Manganese Oxides, Estuar. Coast. Shelf Sci., 50(3), 355-371, doi:10.1006/ecss.1999.0573, 2000.

Walling, D. E., Owens, P. N., Waterfall, B. D., Leeks, G. J. L. and Wass, P. D.: The particle size characteristics of fluvial suspended sediment in the Humber and Tweed catchments, UK, Sci. Total Environ., 251-252, 205-222, doi:10.1016/S0048-9697(00)00384-3, 2000.

Wheatcroft, R. A., Jumars, P. A., Smith, C. R. and Nowell, A. R. M.: A mechanistic view of the particulate biodiffusion coefficient: step lengths, rest periods and transport directions, J. Mar. Res., 48(1), 177-207, 1990.

$\mathrm{Xu}, \mathrm{Z}$. and Han, G.: Rare earth elements (REE) of dissolved and suspended loads in the Xijiang River, South China, Appl. Geochem., 24(9), 1803-1816, doi:10.1016/j.apgeochem.2009.06.001, 2009.

Xu, Z., Lim, D., Choi, J., Yang, S. and Jung, H.: Rare earth elements in bottom sediments of major rivers around the Yellow Sea: implications for sediment provenance, Geo-Mar. Lett., 29(5), 291-300, doi:10.1007/s00367-009-0142-x, 2009.

Yang, S., Li, C., Lee, C. B. and Na, T. K.: REE geochemistry of suspended sediments from the rivers around the Yellow Sea and provenance indicators, Chin. Sci. Bull., 48(11), 11351139, 2003.

Yang, S. Y., Jung, H. S., Choi, M. S. and Li, C. X.: The rare earth element compositions of the Changjiang (Yangtze) and Huanghe (Yellow) river sediments, Earth Planet. Sci. Lett., 201(2), 407-419, doi:10.1016/S0012-821X(02)00715-X, 2002.

Zhang, C., Wang, L., Zhang, S. and Li, X.: Geochemistry of rare earth elements in the mainstream of the Yangtze River, China, Appl. Geochem., 13(4), 451-462, 1998.

Zwolsman, J. J. G. and van Eck, G. T. M.: Geochemistry of major elements and trace metals in suspended matter of the Scheldt estuary, southwest Netherlands, Mar. Chem., 66(1-2), 91111, doi:10.1016/S0304-4203(99)00026-2, 1999.

Zwolsman, J. J. G. and Van Eck, G. T. M.: Dissolved and particulate trace metal geochemistry in the Scheldt estuary, SW Netherlands (water column and sediments), Netherland J. Aquat. Ecol., 27(2-4), 287-300, 1993. 


\subsection{Table}

Table 1: Summary of dataset. Al and Fe content are in $\%$ and $\mathrm{Mn}$ in $\mathrm{mg}^{\mathrm{kg}}{ }^{-1}$ of dry sediment $( \pm 1 \sigma) . \mathrm{n}$ is the number of stations sampled for each location and each campaign. Each kind of analysis (total metal content, rare earth elements and ascorbate extracted content) is performed on a specific aliquot.

\subsection{Figures}

Figure 1: Location of the sampling stations. Black crosses: coastal stations sampled during the May campaign. The dotted rectangle delineates coastal stations sampled during the September campaign only.

Figure 2: (a) Total Fe (\%) vs. Al (\%) and (b) Mn (mg kg-1) vs. Al (\%) for September 2012 (triangles), May 2013 (diamonds) and February 2014 (circles). The colours correspond to location: white for downstream particles, black for upstream. Solid lines correspond to mixing between metal rich particles end members (red stars) and metal poor particles end member (blue star). Data for the estuary and the sediment (not shown) are spread within the two solid lines.

Figure 3: Sediment profiles of iron and manganese concentration extracted by ascorbate and total extraction. The grey zone represents the range of ascorbate extractions for suspended particles in the estuary (February 2014, $\mathrm{n}=12$ ).

Figure 4: Rare earth spectra normalized on PAAS spectrum and thorium concentration for end-member samples: riverine SPM in black; coastal SPM in blue (dark grey) and sediment samples in orange (clear grey).

Figure 5: REE signature according to SPM concentration (log scale) and $\mathrm{Fe}_{\text {asc }}$ content. Ce/La and $\mathrm{Eu} / \mathrm{Sm}$ ratios are normalized on PAAS ratios. Sediment is represented arbitrarily with a particle concentration of $3000 \mathrm{mg} \mathrm{L}^{-1}$.

Figure 6: Relation between ascorbate and total extraction in the estuary after normalization on Al content for (a) Fe and (b) Mn. Panel (c) corresponds to a zoom of the rectangle from panel (a). No data for $\mathrm{Fe}_{\mathrm{asc}}$ content of upstream and downstream particles are available.

Figure 7: Evolution of $\mathrm{Fe} / \mathrm{Al}$ ratio according to salinity for high discharge campaigns $(>1500$ m s ). 


\subsection{Supplementary materials}

Table S1: ANOVA performed on $\mathrm{Fe} / \mathrm{Al}$ and $\mathrm{Mn} / \mathrm{Al}$ ratio from upstream samples, according to the date (day of sampling) and the station (Mont Jean, Tabarly, Oudon or Basse Indre).

Figure S1: Hydrological context of the 3 campaigns (red arrows). The black line represents daily flow. Dotted and grey lines represent median flow and 20 and 80 percentile of the monthly flow. Data source: DREAL Pays de la Loire.

Figure S2: Certified material results. The solid line shows the average of 15 analyses (error bars represent twice the standard deviation) and the dotted line BCR-667 proposed values. Represented values are normalized on PAAS (Post Archean Australian Shale; Taylor and McLennan. 1985).

Figure S3: Manganese and aluminum content of upstream SPM according to a mixing between low flow particles and high flow particles (high SPM concentration).

Figure S4: Evolution of metals content of estuarine and coastal SPM according to SPM concentration. The red vertical line indicates the MTZ boundary, defined as the maximal SPM concentration observed in freshwater. 


\begin{tabular}{|c|c|c|c|c|c|c|c|c|c|c|c|c|c|c|}
\hline Location & Type & Date & $\mathrm{n}$ & SPM $\left(m g \cdot L^{-1}\right)$ & $\mathrm{Al}(\%)$ & $\mathrm{Fe}(\%)$ & $\mathrm{Mn}$ (ppm) & $\mathrm{n}$ & ¿REE (ppm) & $n$ & $\mathrm{Fe}_{\mathrm{asc}}(\%)$ & $\mathrm{Mn}_{\mathrm{asc}}(\mathrm{ppm})$ & $\mathrm{Fe}_{\mathrm{asc}} / \mathrm{Fe}^{\star} 100$ & $\mathrm{Mn}_{\text {ass }} / \mathrm{Mn}^{*} 100$ \\
\hline Riverine & SPM & Sept 2012 & 1 & 269 & 9.41 & 5.34 & 896 & & & & & & & \\
\hline Riverine & SPM & May 2013 & 15 & $33 \pm 19$ & $8.35 \pm 0.88$ & $4.72 \pm 0.36$ & $1073 \pm 240$ & 4 & $137 \pm 6$ & & & & & \\
\hline Riverine & SPM & Feb 2014 & 28 & $33 \pm 13$ & $8.78 \pm 0.87$ & $4.85 \pm 0.55$ & $1040 \pm 215$ & & & & & & & \\
\hline Estuarine & SPM & Sept 2012 & 24 & $354 \pm 525$ & $8.55 \pm 0.41$ & $4.67 \pm 0.26$ & $1141 \pm 169$ & 4 & $489 \pm 180$ & & & & & \\
\hline Estuarine & SPM & May 2013 & 22 & $50 \pm 85$ & $7.97 \pm 0.74$ & $4.31 \pm 0.34$ & $938 \pm 223$ & 22 & $202 \pm 129$ & & & & & \\
\hline Estuarine & SPM & Feb 2014 & 20 & $140 \pm 175$ & $8.52 \pm 0.24$ & $4.40 \pm 0.22$ & $959 \pm 111$ & 18 & $164 \pm 49$ & 12 & $0.65 \pm 0.15$ & $700 \pm 73$ & $15 \pm 3$ & $70 \pm 10$ \\
\hline Coastal & SPM & Sept 2012 & 7 & $5 \pm 3$ & $4.29 \pm 2.29$ & $2.08 \pm 1.14$ & $722 \pm 206$ & & & & & & & \\
\hline Coastal & SPM & May 2013 & 25 & $9 \pm 9$ & $5.45 \pm 1.58$ & $2.60 \pm 0.73$ & $419 \pm 159$ & 25 & $89 \pm 43$ & & & & & \\
\hline Coastal & SPM & Feb 2014 & & & & & & & & & & & & \\
\hline Estuary & Sediment & Sept 2012 & 16 & & $7.02 \pm 0.30$ & $3.88 \pm 0.22$ & $522 \pm 64$ & & & 16 & $0.29 \pm 0.07$ & $145 \pm 43$ & $8 \pm 2$ & $26 \pm 5$ \\
\hline Estuary & Sediment & May 2013 & 15 & & $7.69 \pm 0.19$ & $4.24 \pm 0.16$ & $761 \pm 232$ & 8 & $199 \pm 7$ & 15 & $0.32 \pm 0.07$ & $267 \pm 174$ & $8 \pm 2$ & $33 \pm 8$ \\
\hline Estuary & Sediment & Feb 2014 & 32 & & $7.70 \pm 0.59$ & $4.16 \pm 0.40$ & $926 \pm 336$ & 6 & $195 \pm 11$ & 32 & $0.49 \pm 0.12$ & $503 \pm 338$ & $12 \pm 2$ & $49 \pm 19$ \\
\hline
\end{tabular}

Table 1: Summary of dataset. Al and Fe content are in $\%$ and $\mathrm{Mn}$ in $\mathrm{mg} \cdot \mathrm{kg}^{-1}$ of dry sediment $( \pm 1 \sigma) . \mathrm{n}$ is the number of stations sampled for each location and each campaign. Each kind of analysis (total metal content, rare earth elements and ascorbate extracted content) is performed on a specific aliquot. 


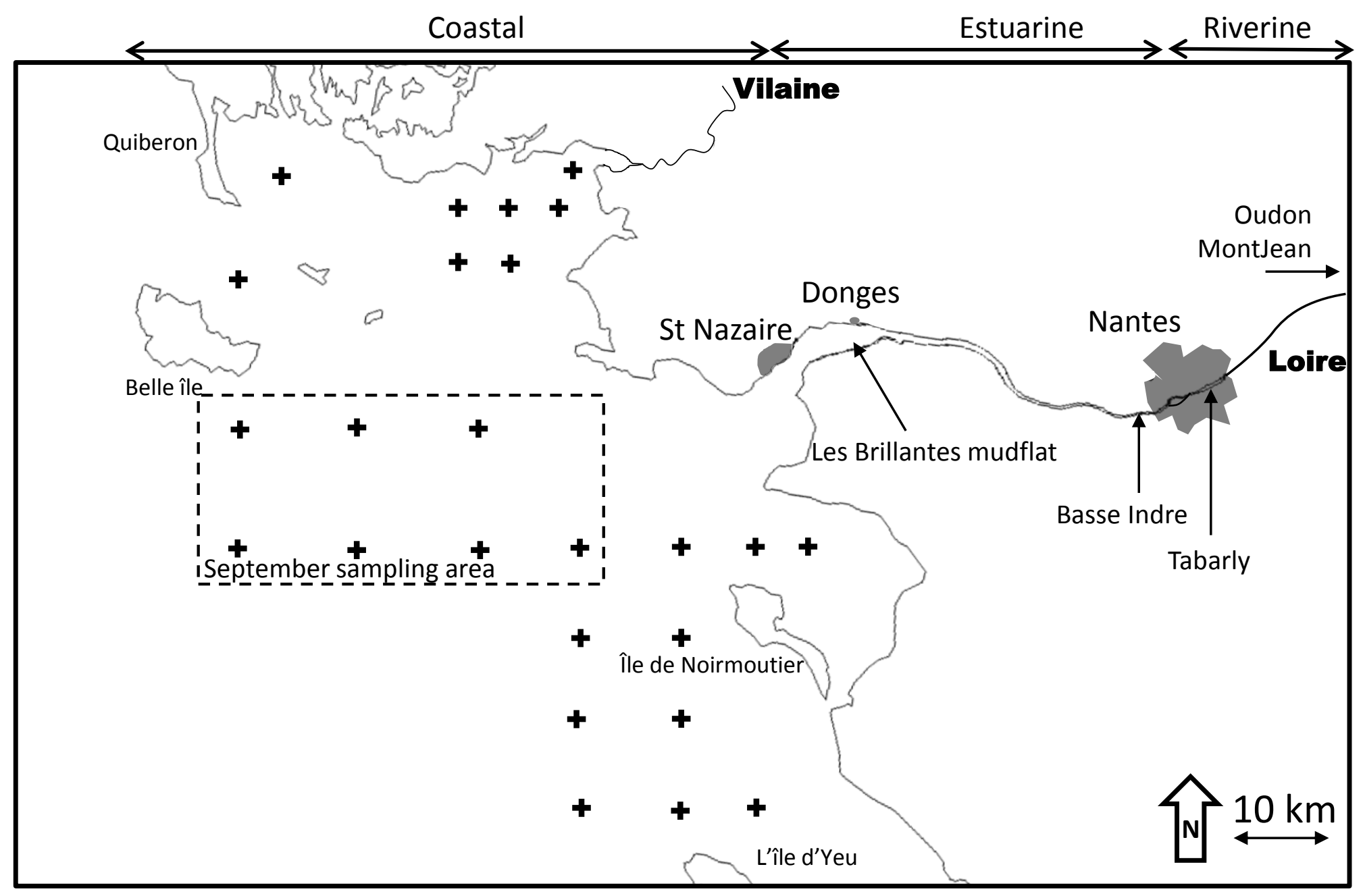

Figure 1: Location of the sampling stations. Black crosses: coastal stations sampled during the May campaign. The dotted rectangle delineates coastal stations sampled during the September campaign only. 


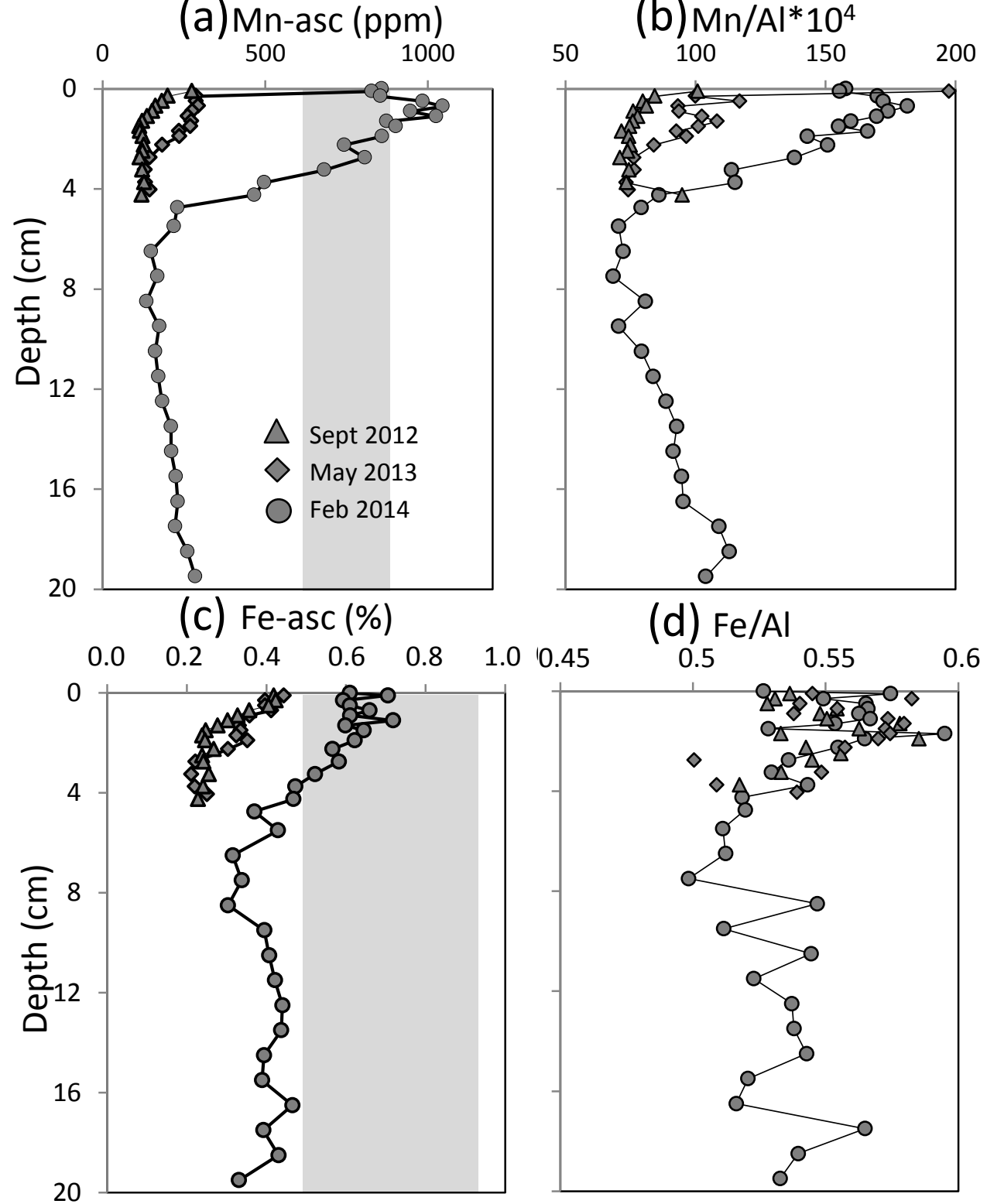

Figure 3: Sediment profiles of iron and manganese concentration extracted by ascorbate and total extraction. The grey zone represents the range of ascorbate extractions for suspended particles in the estuary (February 2014, $n=12$ ). 


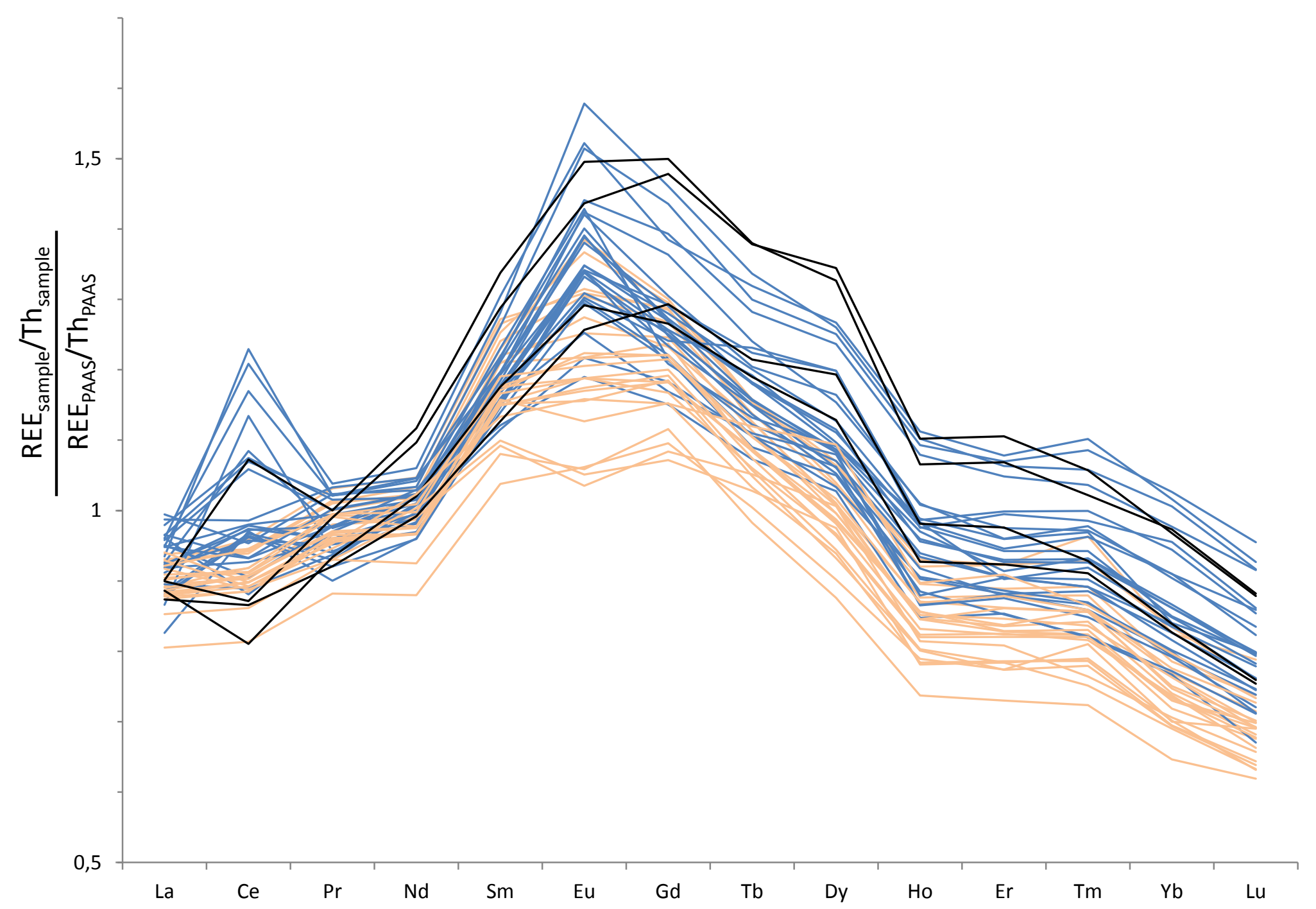

Figure 4: Rare earth spectra normalized on PAAS spectrum and thorium concentration for end-member samples: riverine SPM in black; coastal SPM in blue (dark grey) and sediment samples in orange (clear grey). 


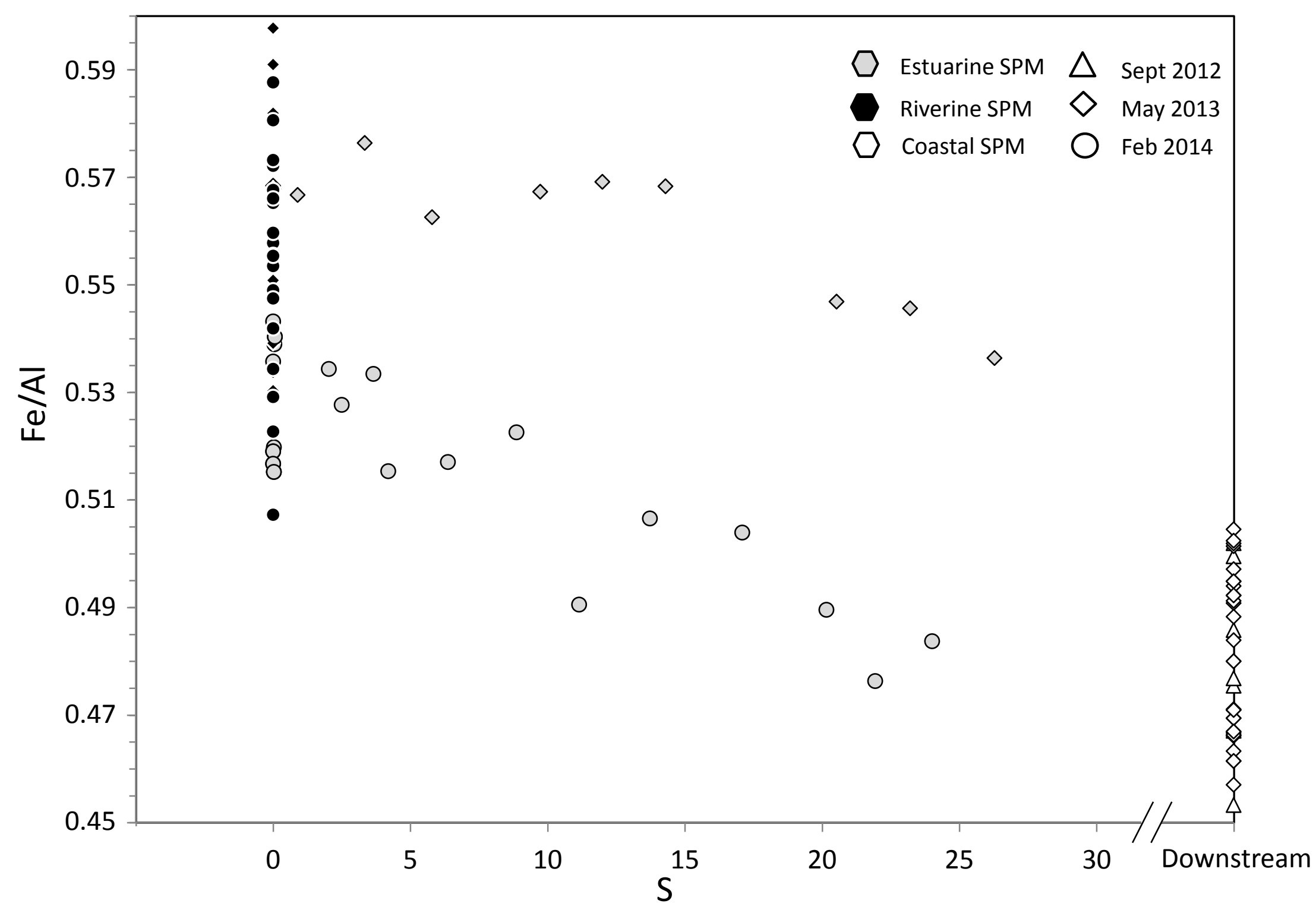

Figure 7: Evolution of Fe/Al ratio according to salinity for high discharge campaigns $\left(>1500 \mathrm{~m}^{3} \mathrm{~s}^{-1}\right)$. 


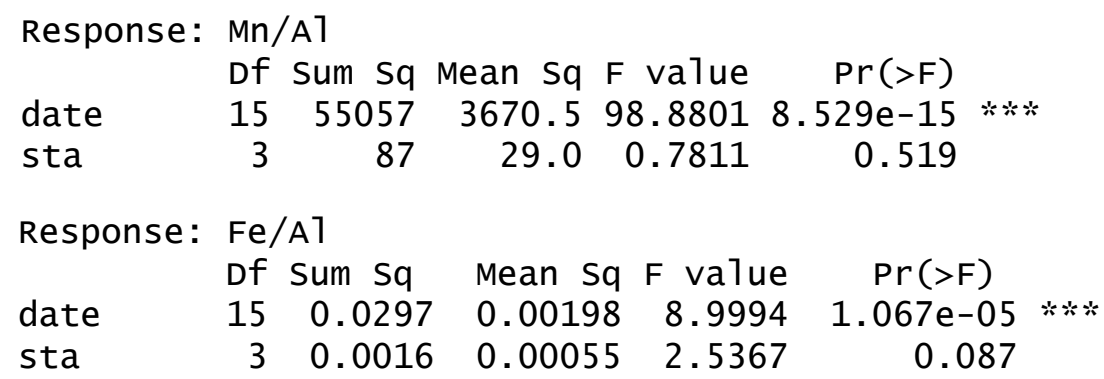

Table S1: ANOVA performed on Fe/Al and Mn/Al ratio from upstream samples, according to the date (day of sampling) and the station (Mont Jean, Tabarly, Oudon or Basse Indre). 


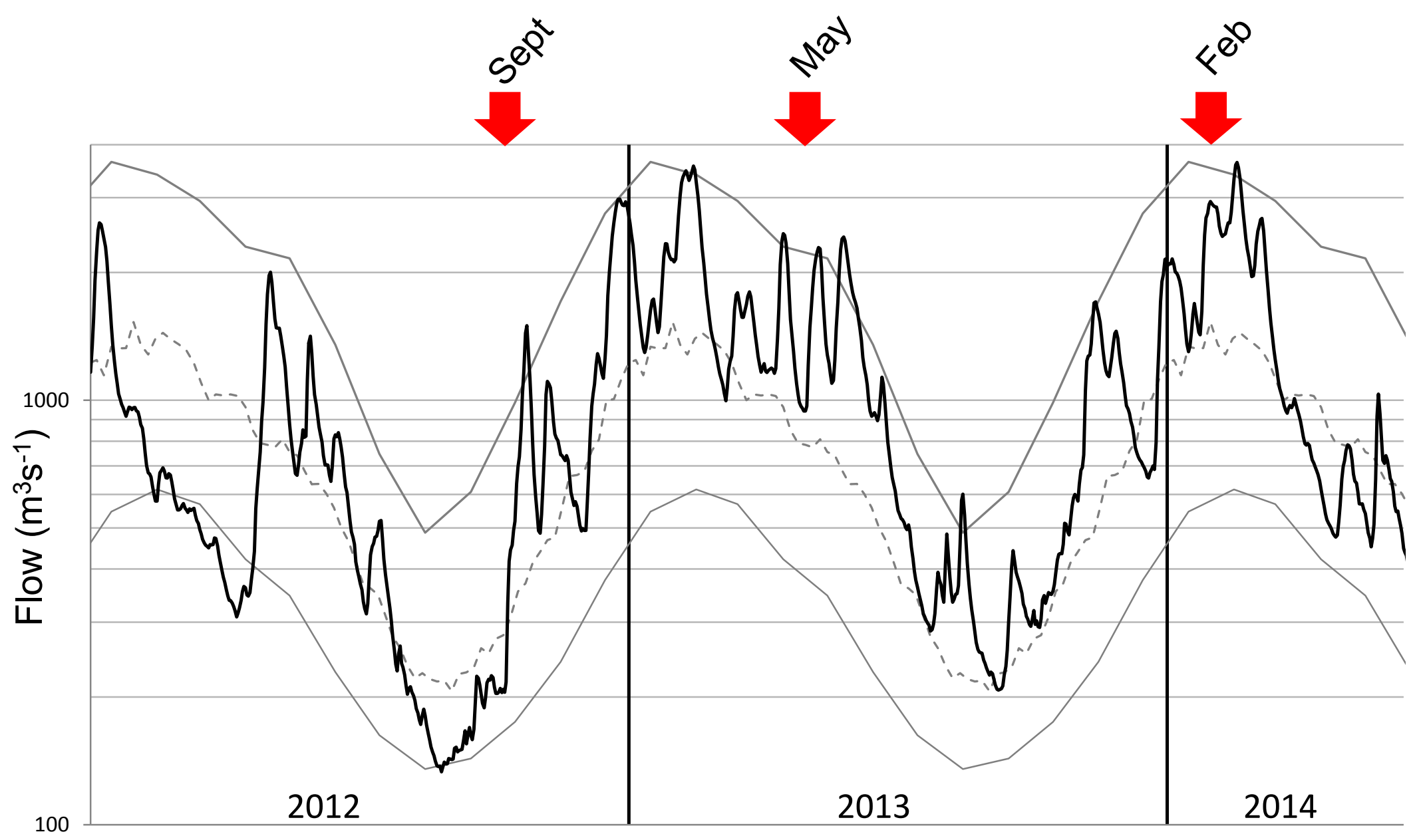

Figure S1: Hydrological context of the 3 campaigns (red arrows). The black line represents daily flow. Dotted and grey lines represent median flow and 20 and 80 percentile of the monthly flow. Data source: DREAL Pays de la Loire. 


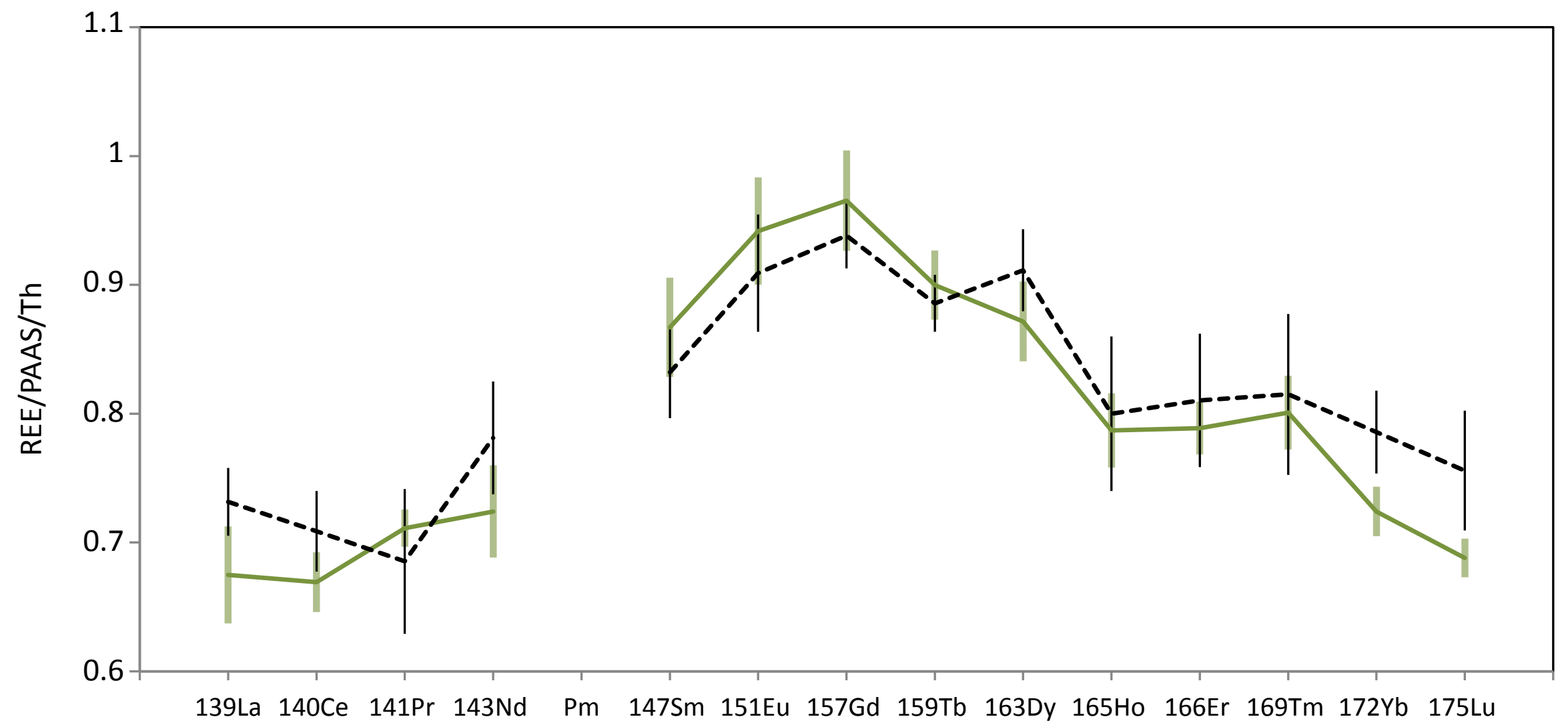

Figure S2: Certified material results. The solid line shows the average of 15 analyses (error bars represent twice the standard deviation) and the dotted line BCR-667 proposed values. Represented values are normalized on PAAS (Post Archean Australian Shale; Taylor and McLennan. 1985). 
